\title{
A Sociologia no Brasil: história, teorias e desafios
}

ENNO D. LIEDKE FILHO*

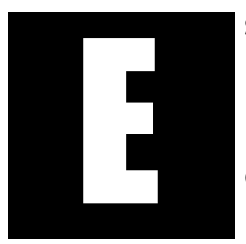

ste estudo focaliza a história da Sociologia no Brasil, analisando os traços principais das etapas e períodos de sua institucionalização e evolução como disciplina acadêmico-científica, as recepções de tradições sociológicas européias e norte-americana pela sociologia brasileira, assim como a situação atual da Sociologia, os principais campos de pesquisa, os novos temas e novas abordagens que vieram a ser propostos para a explicação e/ou compreensão da situação social brasileira.

A emergência e evolução da Sociologia como disciplina acadêmicocientífica no Brasil e na América Latina divide-se nas seguintes etapas e períodos:

A Herança Histórico-cultural da Sociologia

Período dos Pensadores Sociais

Período da Sociologia de Cátedra

Etapa Contemporânea da Sociologia

Período da Sociologia Científica

Período de Crise e Diversificação

\footnotetext{
* Professor Colaborador do Programa de Pós-Graduação em Sociologia da Universidade Federal do Rio Grande do Sul, Porto Alegre, Brasil.
} 
Período de Busca de uma Nova Identidade ${ }^{1}$

Os principais acontecimentos, características institucionais, bem como as problemáticas, os temas e as influências teóricas dominantes ao longo dessas etapas e períodos da evolução da Sociologia no Brasil, apresentados esquematicamente na Figura 1, serão analisados em detalhe a seguir.

\section{I - A Herança Histórico-cultural da Sociologia no Brasil}

- O período dos pensadores sociais

O período dos Pensadores Sociais, também chamado por alguns autores de período pré-científico, corresponde historicamente ao período que se estende das lutas pela Independência das nações latino-americanas até o início do século XX. Durante esse período a elaboração de teoria social tendeu a ser desenvolvida por pensadores e mesmo homens de ação (políticos), sob a influência de idéias filosófico-sociais européias ou norte-americanas como, por exemplo, o iluminismo francês, o ecletismo de Cousin, o positivismo de Comte, o evolucionismo de Spencer e Haeckel, o social-darwinismo americano de Sumner e Ward e o determinismo biológico de Lombroso. Sob as influências desses autores buscava-se equacionar duas problemáticas centrais - a formação do Estado nacional brasileiro, opondo liberais e autoritários, ${ }^{2}$ e a questão da identidade nacional, tendo como núcleo a questão racial opondo os que sustentavam uma visão racista e os inspirados pelo relativismo étnico-cultural. ${ }^{3}$

\footnotetext{
1 A reconstrução da evolução da sociologia no Brasil e na América Latina apresentada aqui sucintamente, foi desenvolvida , em detalhe em Liedke Filho (1990a).

2 Sobre o pensamento autoritário na Primeira República, ver Lamounier, 1977.

3 Entre outros, ver Maio, 1996.
} 


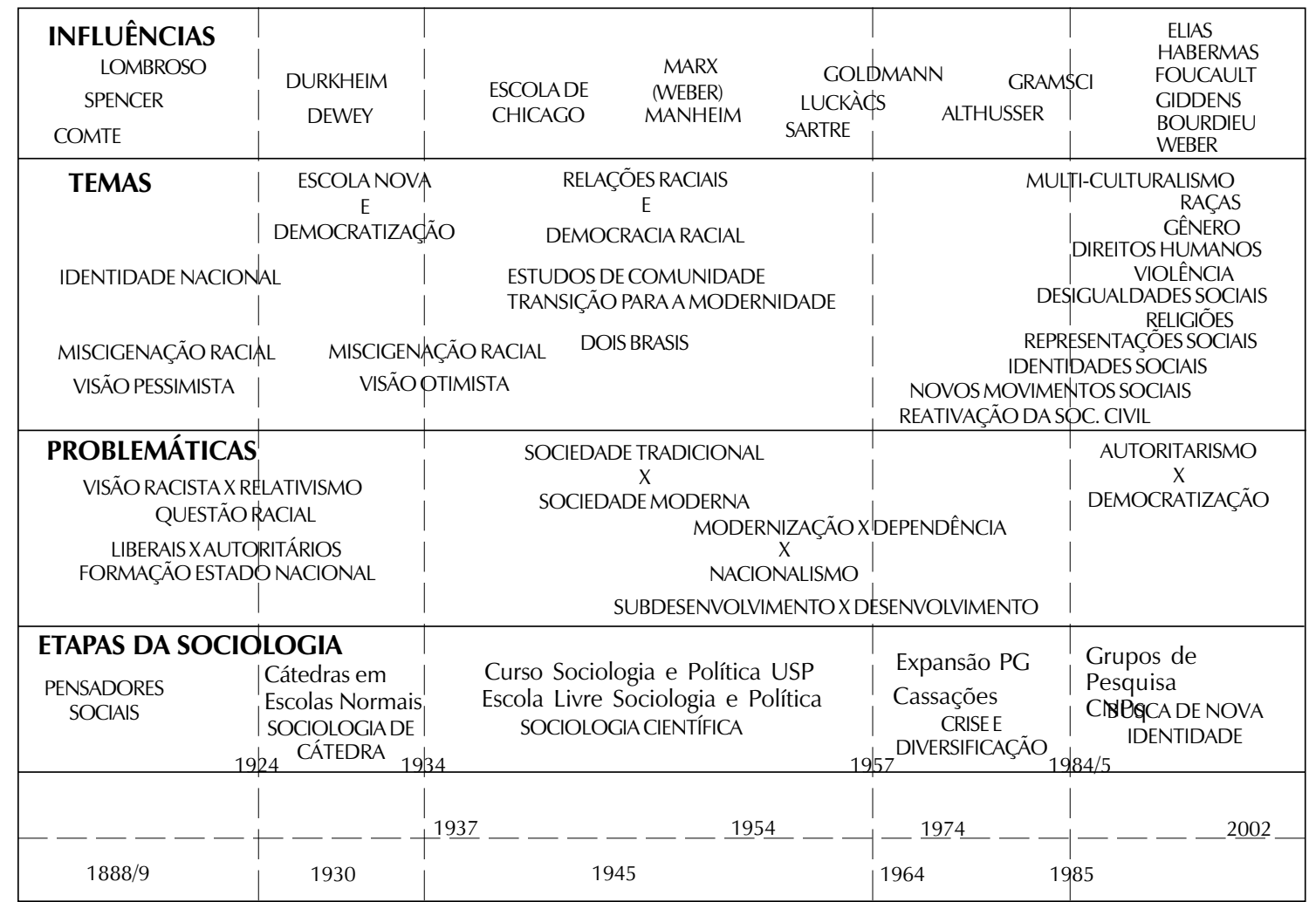

Figura 1 - A Sociologia no Brasil 
Azevedo (1957 e 1962) sugere que a evolução dos estudos de Antropologia e de Sociologia sobre a sociedade brasileira apresenta uma etapa anterior ao ensino e à pesquisa, a qual se estende da segunda metade do século XIX até $1928 ;{ }^{4}$ caracterizada predominantemente pelas grandes expedições de investigação científica das culturas indígenas (1818 a 1910), quando

...sábios alemães e de outras nacionalidades ... se puseram em contato com grande número de tribos, (abrindo) novas perspectivas aos estudos etnológicos e, com as obras (resultantes) trouxeram contribuição notável aos progressos nesse vasto domínio de investigações científicas (Azevedo, 1962, p. 111).

Paralelamente ao florescimento dos estudos sobre as tribos indígenas e, no entender de Azevedo, sob a influência destes, iniciaram-se os estudos de Antropologia Física e Cultural tendo por temática principal os negros e as culturas africanas no Brasil, destacando-se autores tais como Batista Lacerda, Nina Rodrigues e Roquette Pinto. Os estudos sobre as tribos indígenas e os negros no Brasil, ao prepararem o caminho para a posterior institucionalização do ensino e da pesquisa, constituíram o ponto de partida para a evolução da sociologia propriamente dita (Azevedo, 1962).

Azevedo considera que esta etapa dos precursores ou pioneiros da nova ciência no Brasil, autodidatas, eruditos ou diletantes que cediam a influências variáveis e sucessíveis de obras que lhes caíam nas mãos e passavam a ser as fontes inspiradoras de seus trabalhos, significou a acentuação do pensamento sociológico e político, a princípio tênue e difuso, tendo por referências o positivismo, o evolucionismo e as influências da escola antropológica italiana, as teorias antropogeográficas e, finalmente, da ecologia humana e da antropologia cultural anglo-americana (Azevedo, 1962).

4 Esta etapa foi, no entender de Azevedo, antecedida por uma fase pré-científica caracterizada pela contribuição etnográfica dos cronistas (séculos XVI-XVIII) 
Sobre o sentido social das ciências sociais neste período dos pensadores sociais, é interessante deixar também registrado aqui que Fernandes (1977), analisando as razões pelo interesse nos conhecimentos sociológicos, então indica que podem ser identificados dois períodos: um primeiro período de autodidatismo inicia-se já no terceiro quartel do século XIX, correspondendo à fase de desagregação da ordem social escravocrata, e é caracterizado pela exploração de conhecimentos sociológicos como recurso parcial de interpretação. A intenção principal não é fazer investigação sociológica propriamente dita, mas considerar fatores sociais na análise de certas relações como, por exemplo, as conexões entre o Direito e a Sociologia, a literatura e o contexto social, o Estado e a organização social. Um segundo período tem início em princípios do século, quando a sociologia frutifica "tanto sob a forma de análise histórico-geográfica como sociológica do presente, quanto sob a inspiração de um modelo mais complexo de análise histórico-pragmática, em que a interpretação do presente se associa a disposições de intervenção racional no processo social" (Fernandes, 1977, p. 27).

- O período da Sociologia de Cátedra

O período da Sociologia de Cátedra iniciou-se nos países latino-americanos em fins do século passado, quando cátedras de Sociologia foram introduzidas nas Faculdades de Filosofia, Direito e Economia. No Brasil, esse período teve início em meados da década de vinte, quando foram criadas as primeiras cátedras de Sociologia em Escolas Normais (1924-25), enquanto disciplina auxiliar da pedagogia, dentro do esforço democratizante do movimento reformista pedagógico que tem sua expressão maior no movimento da Escola Nova. Neste momento, ocorreu a proliferação de publicações como os manuais e coletâneas para o ensino de Sociologia, os quais procuravam divulgar as idéias de cientistas sociais europeus e norte-americanos renomados, tais como Durkheim e Dewey, 
bem como idéias sociológicas acerca de problemas sociais como urbanização, migrações, analfabetismo e pobreza. Ao mesmo tempo, a questão da miscigenação racial no Brasil passou a ser tratada em uma perspectiva otimista como em Casa Grande e Senzala de Gilberto Freyre (2000).

Azevedo (1951), enfocando esta fase de introdução do ensino da Sociologia em escolas do País (1928-1935), argumenta que a origem da consolidação da Sociologia na mesma deve ser procurada, não em uma única causa determinante, senão em múltiplas causas que estão estreitamente ligadas, sendo possível distingui-las unicamente para fins analíticos. A multiplicidade de fatores decorrentes dos contatos, conflitos e acomodações de povos e culturas diversas; o contraste entre as sociedades em mudança e as culturas de folk remanescentes em toda a vasta extensão territorial; a variedade de paisagens culturais e a contemporaneidade ou justaposição nas realidades concretas, de séculos ou de "camadas históricas", deveriam certamente sacudir a atenção e despertar o interesse pelo estudo científico dessas realidades sociais vivas e atuais, postas sob os olhos de todos e que não escaparam, pela intensidade dos fenômenos, aos observadores menos atentos.

Porém, acrescenta Azevedo (1962),

...[o] que nos compeliu a essa revolução intelectual, que nos iniciou no espírito crítico e experimental, em todos os domínios, e nos abriu o caminho aos estudos e as pesquisas sociológicas, foi, no entanto, o desenvolvimento da indústria e do comércio nos grandes centros do país e, particularmente em São Paulo e no Rio de Janeiro (1962, p. 125).

O primeiro surto industrial, em 1918, em conseqüência da guerra mundial, as transformações da estrutura econômica e social que daí resultaram, e a revolução de 1930 que, provocada por essas mudanças, contribuiu para intensificá-las repercutindo nas esferas culturais, devem estar na 
origem da nova atitude crítica na mentalidade das elites novas, dos movimentos de renovação em diversos setores, como nos das letras e das artes, da educação e da política, e do interesse crescente pelos estudos científicos das realidades sociais.

\section{A Etapa Contemporânea da Sociologia no Brasil}

- O período da Sociologia Científica

O início do período da Sociologia Contemporânea corresponde à fase de emergência da Sociologia Científica, que buscava, sob a égide do paradigma estrutural-funcionalista, a consecução de um padrão de institucionalização e prática do ensino e da pesquisa em sociologia, similar ao dos centros sociológicos dos países centrais. A concepção de desenvolvimento desta abordagem teve sua expressão na Teoria da Modernização e em sua análise do processo de transição da sociedade tradicional para a sociedade moderna, sob uma ótica dualista como em Os Dois Brasis de Jacques Lambert (1959).

A institucionalização acadêmica da Sociologia no Brasil ocorreu em meados da década de 1930, com a criação da Escola Livre de Sociologia e Política de São Paulo (1933) e com a criação da Seção de Sociologia e Ciência Política da Faculdade de Filosofia da Universidade de São Paulo (1934). As tentativas, de relacionar o ensino e a pesquisa em Sociologia, ainda que limitadas e parciais em ambas as instituições, demarcam o início da chamada etapa da Sociologia Científica, a qual viria a ter seu apogeu em fins dos anos de 1950.

Nas palavras de Fernandes (1977), configurava-se então plenamente um novo período da Sociologia no Brasil, o qual, embora com raízes no segundo quartel deste século, só se configura plenamente no pós-guerra, tendo por característica dominante a preocupação "de subordinar o labor intelectual, no estudo dos fenômenos sociais, aos padrões de trabalho cien- 
tífico sistemático. Esta intenção se revela tanto nas obras de investigação empírico-indutivas (de reconstrução histórica ou de campo), quanto nos ensaios de sistematização teórica" (Fernandes, 1977, p. 28).

É interessante destacar que a primeira experiência de institucionalização da Sociologia e da Ciência Política no ensino superior no Brasil, ocorrida na Escola Livre de Sociologia e Política de São Paulo, criada pela elite paulista no contexto da derrota da Revolução Constitucionalista de 1932, tinha por objetivo, como explicitado no Manifesto da Fundação da Escola, suprir a falta de "uma elite numerosa e organizada, instruída sob métodos científicos, a par das instituições e conquistas do mundo civilizado, capaz de compreender antes de agir o meio social em que vivemos" (Oliveira, 1933, p. 171). Nessa instituição, sob a influência da Escola de Chicago, representada pelo nome de Donald Pierson, foi realizada uma série de estudos de comunidade, a qual pode ser entendida como um primeiro programa de pesquisa nas ciências sociais brasileiras para o tratamento sistemático da transição da sociedade tradicional para a modernidade.

Azevedo (1951) sugere que a fase iniciada em 1936, de associação do ensino e da pesquisa nas atividades universitárias, tem sua origem não em uma única causa determinante, senão em múltiplas causas que estão estreitamente ligadas, sendo possível distingui-las unicamente para fins analíticos.

A multiplicidade de fatores decorrentes dos contatos, conflitos e acomodações de povos e culturas diversas; o contraste entre as sociedades em mudança e as culturas de folk remanescentes em toda a vasta extensão territorial; a variedade de paisagens culturais e a contemporaneidade ou justaposição nas realidades concretas, de séculos ou de "camadas históricas", deveriam certamente sacudir a atenção e despertar o interesse pelo estudo científico dessas realidades sociais, vivas e atuais, postas sob os olhos de todos e que não escaparam, pela intensidade dos fenômenos, aos 
observadores menos atentos.

Porém, acrescenta Azevedo (1951),

...[o] que nos compeliu a essa revolução intelectual, que nos iniciou no espírito crítico e experimental, em todos os domínios, e nos abriu o caminho aos estudos e as pesquisas sociológicas, foi, no entanto, o desenvolvimento da indústria e do comércio nos grandes centros do país e, particularmente em São Paulo e no Rio de Janeiro (Azevedo, 1962, p. 125).

O primeiro surto industrial, em 1918, em conseqüência da guerra mundial, as transformações da estrutura econômica e social que daí resultaram, e a revolução de 1930 que, provocada por essas mudanças, contribuiu para intensificá-las repercutindo nas esferas culturais, devem estar na origem da nova atitude crítica na mentalidade das elites novas, dos movimentos de renovação em diversos setores, como nos das letras e das artes, da educação e da política, e do interesse crescente pelos estudos científicos das realidades sociais.

Outrossim, Costa Pinto referindo-se ao caso das ciências sociais no Brasil nesse período, afirma que:

no espaço de pouco mais de uma década as continências da vida brasileira fizeram a ideologia das elites dirigentes passar da quase "coqueluche"para o quase pânico diante delas. É que, se a ausência delas significava problemas, a sua expansão poderia acarretar outros problemas igualmente temidos. No caso, mais de uma vez, a timidez ideológica pagou ônus do duplo medo: o medo do problema e o medo da solução dele, que é uma nota constante do comportamento das elites brasileiras nos últimos tempos.

Esta ambivalência das elites frente às ciências sociais por vezes implica na criação de condições institucionais e financeiras favoráveis e por vezes desfavoráveis para o 
desenvolvimento de recursos humanos e para a criação, expansão e consolidação de centros de pesquisa e mercado de trabalho para sociólogos...(Costa Pinto, 1955, p. 28-29).

Se as circunstâncias do Estado Novo representaram um obstáculo ao florescimento das atividades de ensino e pesquisa em Sociologia (Costa Pinto, 1955), a redemocratização de 1945 e principalmente a mobilização político-ideológica dos anos 50 e 60 criaram condições favoráveis à expansão dessas atividades.

Costa Pinto (1955) indica os principais temas enfocados pelas ciências sociais no Brasil em meados da década dos cinqüenta: população, imigração e colonização; - relações étnicas, contatos e assimilação (o negro; o índio e o branco colonizador); - educação; - história social; - Direito e Ciência Política; - estudos de comunidades; análises regionais e Sociologia rural e urbana. Nesse período, os seguintes temas ocupavam também posição de relevo na produção das ciências sociais brasileiras: a elaboração de manuais para o ensino de Sociologia em escolas secundárias; teoria e método das ciências sociais (incluindo a tradução e divulgação de livros estrangeiros especializados); folclore; sociologia da arte e da literatura, psicologia social e, em campos marginais entre a Sociologia e a Economia, os estudos de padrão de vida e as pesquisas de estratificação, mobilidade e sociologia ocupacional (Costa Pinto, 1955).

Esta etapa tem como um de seus marcos principais a formação da chamada "Escola de Sociologia Paulista" ou "Escola da USP" com a organização do grupo originário de sociólogos em 1954, sob a direção de Florestan Fernandes, que desenvolveu projetos coletivos de pesquisa acerca das relações raciais no Brasil, da empresa industrial em São Paulo e do desenvolvimento brasileiro (Liedke Filho, 1977; Ianni, 1975; Fernandes, 1977; Sorj e Mitre, 1985; Nogueira, 1982). A preocupação com as possibilidades de um desenvolvimento democrático, racional, urbano-industrial da sociedade brasileira, enquanto concepção particular da Teoria da Modernização, ocu- 
pou um papel central entre as orientações intelectuais e políticas do "projeto" da "Escola" neste período (Liedke Filho, 1977).

Os anos 50 foram marcados também pelo surgimento da proposta de uma "Sociologia Autêntica", nacionalista, que buscava contribuir para o processo de libertação nacional e que tem na obra de Guerreiro Ramos (1957 e 1965) sua referência principal. Teoricamente, a controvérsia entre Guerreiro Ramos e Florestan Fernandes dominou a cena da comunidade sociológica brasileira durante esse período, tendo por fulcro central a questão da particularidade e/ou universalidade do conhecimento social produzido no Brasil (Ramos, 1957 e 1965; Fernandes, 1957 e 1958).

A Teoria da Modernização concebe o processo de desenvolvimento como uma transição de uma sociedade rural tradicional para uma sociedade industrial moderna (Germani, 1969). Essa transição, quando incompleta, acarreta a coexistência de ambas as formas societárias dentro de uma mesma sociedade nacional, caracterizando-a como uma sociedade dual (Quadro 1). Ressalte-se que esta tese teve ampla aceitação internacional na sociologia do desenvolvimento, assim como no âmbito das agências internacionais como a UNESCO.

Quadro 1 - Teoria da Modernização - características da sociedade tradicional e da sociedade moderna

\begin{tabular}{|cc|}
\hline & \\
SOCIEDADE TRADICIONAL & SOCIEDADE MODERNA \\
RURAL & URBANO-INDUSTRIAL \\
ESTAGNADA & DINÂMICA \\
RELAÇÓES PRIMÁRIAS & RELAÇÓES SECUNDÁRIAS \\
"COMUNIDADE" & "SOCIEDADE" \\
ILETRADA & LETRADA \\
RELIGIOSA & SECULARIZADA \\
\hline
\end{tabular}

Fonte: Stavenhagen (1969) 
Rodolfo Stavenhagen (1965) aponta que a tese de que "os países latino-americanos são sociedades duais", assume que esses países são constituídos por duas sub-sociedades, caracterizadas nos seguintes termos:

A "sociedade arcaica" seria caracterizada por relações de tipo essencialmente familiar e pessoal, por instituições tradicionais (o compadrio, certas formas de trabalho coletivo, de dominação personalista e de clientela política, etc.), por uma estratificação social rígida de status adscritos (isto é, em que a posição do indivíduo na escala social está determinada desde o nascimento, com poucas possibilidades de mudança durante a vida), e por normas e valores que exaltam, ou, quando menos, aceitam, o status quo, os estilos de vida herdados dos antepassados, e que constituem obstáculo ao pensamento econômico "racional".

A sociedade "moderna", pelo contrário, consistiria em relações sociais do tipo que os sociólogos chamam de "secundárias", determinadas pelas ações interpessoais destinadas a fins racionais e utilitários; de instituições funcionais, de estratificação social pouco rígida (isto é, com mobilidade social) em que abundam os status adquiridos por meio do esforço pessoal e determinados, seja por índices quantitativos (como o são o nível de renda ou o grau educacional), seja por funções sociais (como a ocupação). Na "sociedade moderna", as normas e os valores das pessoas tendem a orientar-se para a mudança, o progresso, as inovações e a racionalidade econômica (a saber, o cálculo de maiores lucros com menores custos) (Stavenhagen, 1969, p. 122).

No entender de Stavenhagen, a tese da existência de uma "sociedade dual" é equivocada por duas razões principais:

Primeiro, porque os dois pólos são o resultado de um 
único processo histórico e, segundo, porque as relações mútuas que mantêm entre si as regiões e grupos "arcaicos" ou "feudais" e os "modernos" ou "capitalistas" representam o funcionamento de uma única sociedade global da qual ambos os pólos são parte integrante (Stavenhagen, 1969, p. 123).

Como curiosidade, tem-se no Quadro 2, o conjunto das teses equivocadas sobre a América Latina, vigentes no início dos anos sessenta, as quais são objeto de análise no texto de Stavenhagen. Destaque-se que, das sete teses, quatro delas - Teses 2, 3 e 5 -, são variações da tese básica da Teoria da Modernização, acima apresentada.

Quadro 2 - Rodolfo Stavenhagen - sete teses equivocadas sobre a América Latina

1 - Os países latino-americanos são sociedades duais.

2 - O progresso da América Latina realizar-se-á mediante a difusão dos produtos do industrialismo às zonas atrasadas, arcaicas e tradicionais.

3 - A existência de zonas rurais atrasadas, tradicionais e arcaicas é um obstáculo para a formação do mercado interno e para o desenvolvimento do capitalismo nacional e progressista.

4 - A burguesia nacional tem interesse em romper o poder e o domínio da oligarquia latifundiária.

5 - O desenvolvimento na América Latina é obra e criação de uma classe média nacionalista, progressista, empreendedora e dinâmica, e o objetivo da política sócio-econômica de nossos governos deve ser o de estimular a "mobilidade social" e o desenvolvimento desta classe.

6 - A integração nacional na América Latina é produto da miscigenação.

7 - O progresso na América Latina só se realizará mediante aliança entre operários e camponeses, aliança que impõe identidade de interesses destas duas classes. 
É interessante ter presente que, quanto à Sociologia e seu significado societário, as explicações propostas dentro do campo da Teoria da Modernização tendem a enfatizar as condições societárias, normativas e institucionais necessárias ao desenvolvimento da "sociologia científica", enfocando as "atitudes favoráveis e desfavoráveis" a este, bem como o "efeito-demonstração" exercido pelos centros sociológicos dos países centrais sobre a sociologia latino-americana (Costa Pinto, 1955; Fernandes, 1977; Germani, 1959; Ianni, 1971a).

A "Sociologia Científica" caracterizada pela "adoção dos princípios básicos do conhecimento científico em geral, embora tenha suas próprias especificidades", assim como pelo "desenvolvimento de procedimentos de pesquisa extremamente refinados e muito mais poderosos do que os previamente utilizados". As conseqüências disso são uma "tecnificação crescente da Sociologia, dada a estandardização dos procedimentos de pesquisa, o uso generalizado de instrumentos selecionados de pesquisa, a 'rotinização e coletivização das atividades, a necessidade crescente de recursos financeiros, espaços físicos e equipamentos, e de pessoal técnico e administrativo" (Germani, 1964). Portanto, a consecução deste projeto intelectual implica alcançar um padrão de ensino e pesquisa similar àquele dos países centrais onde a "Sociologia Científica" foi formulada originalmente.

Esperar-se-ia que um patamar superior de modernização societária, caracterizada pela evolução para uma "sociedade racional, democrática e urbano-industrial" levaria à institucionalização plena da "Sociologia Científica", típica da terceira etapa de evolução da Sociologia na América Latina. Esta abordagem sustenta, portanto, uma estreita associação entre modernização, democratização e condições favoráveis à evolução da Sociologia.

A emergência dos "novos" regimes autoritários latino-americanos, a partir da década de sessenta, e seus impactos negativos sobre a práxis sociológica na região vieram a ser interpretados como "obstáculos" à consolidação da sociologia científica (Germani, 1969; Fernandes, 1977). 
Uma "crise" da Sociologia seria interpretada seja como um sinal de "imaturidade" das ciências sociais ou como uma disfunção entre os requisitos universais-normativos da ciência e os interesses e atitudes sociais, sendo concebida em ambos os casos como uma fase transitória que, uma vez superada implicaria no florescimento pleno da "Sociologia Científica".

Por outro lado, a abordagem fundamentada na Teoria do NeoColonialismo ou Neo-Imperialismo, (assim como uma versão simplista da Teoria da Dependência, conforme abaixo sugerido) assume que a persistência de uma situação neocolonial ou dependente implica estagnação econômica e formas políticas autoritárias e, conseqüentemente, em um clima cultural desfavorável à evolução das ciências sociais (Ramos, 1957; Carri, 1970).

Ao mesmo tempo, esta abordagem enfatiza que a persistência da influência intelectual dos centros de sociologia dos países centrais sobre a Sociologia latino-americana acarreta a predominância de uma sociologia neocolonialista ou dependentista (Ramos, 1957 e 1965; Carri, 1970), valorizando, pois, este processo, de forma oposta à Teoria da Modernização, que concebe positivamente o "efeito-demonstração" em geral, e no nível da Sociologia em particular.

Por outro lado, a possibilidade de emergência e consolidação de uma "Sociologia Nacional" ou "Autêntica", típica de uma nova etapa a ser alcançada, estaria vinculada à superação da situação neo-colonial ou neoimperialista e uma correspondente consolidação de democracias nacionais populares.

Na ótica da abordagem "Neocolonialismo/Neo-imperialismo" a importação de problemáticas, paradigmas e técnicas sociológicas de "centros imperialistas tem sido denunciada como uma forma de "neo-imperialismo cultural" ou de "alienação cultural", que precisa ser superada pela construção de uma "Sociologia Nacional" como uma autêntica "teoria 
militante da realidade nacional" (Ramos, 1957, p. 26), que visa contribuir para o desenvolvimento de uma consciência nacional pela inter-relação entre o conhecimento e a prática popular (Carri, 1970, p. 164).

A abordagem "nacional" tende a enfatizar a necessidade de uma "crise" da Sociologia dentro da luta pela "libertação nacional" e por uma sociedade nacional popular democrática socialista, como forma de desafiar a "alienação cultural" caracterizada pela dominância da "sociologia cientifica". A elaboração e dominância completa de uma "Sociologia Nacional" (isto é, a formulação de teorias, métodos e técnicas para a análise dos "problemas nacionais") considerada como a única forma possível de superação da "crise" da Sociologia, uma vez que a persistência de qualquer prática da "sociologia cientifica" implicaria na persistência de "neocolonialismo/neo-imperialismo cultural".

A análise desenvolvida por Guerreiro Ramos acerca da Sociologia no Brasil exemplifica essa abordagem. Apontando que a Sociologia como tem sido praticada no Brasil não tem, salvo poucas exceções, representado uma "real indução dos processos e tendências da sociedade brasileira e um instrumento para sua autocompreensão", o autor argumenta que:

A disciplina sociológica, no Brasil e nos países de formação semelhante, como os da América Latina, tem evoluído até agora, segundo influências exógenas que impediam, neles, o desenvolvimento de um pensamento científico autêntico ou em estreita correspondência com as circunstancias particulares desses países. Assim, a disciplina sociológica nesses países se constitui de glosas de atitudes, posições doutrinárias e fórmulas de salvação produzidas alhures, ou ilustra menos o esforço do sociólogo para compreender a sua sociedade, do que para se informar da produção das sociólogos estrangeiros (Ramos, 1956, p.19). 
De outro lado,

... a sociologia, no Brasil, ser autêntica na medida em que colaborar para a autoconsciência nacional, na medida em que ganhar em funcionalidade, intencionalidade e, conseqüentemente, em originalidade. ... Em resumo, sem a disposição para empreender a sua autocrítica, a sociologia no Brasil não poder realizar a sua tarefa essencial - a de tornar-se uma teoria militante da própria realidade nacional (Ramos, 1953, In 1956, p. 26).

Simetria, sincretismo, dogmatismo, dedutivismo, alienação e inautenticidade são as características da "sociologia enlatada" ou "sociologia consular". A simetria e o sincretismo devem-se à adoção imediata, geralmente por justaposição, das orientações européias e norte-americanas mais recentes, sendo que "as orientações e tendências aparecem aqui, simetricamente, na mesma ordem em que surgem lá", e "os nossos autores estão sempre dispostos a fazer aqui a conciliação de doutrinas que, nos próprios países de origem, são incompatíveis" (Ramos, 1957, p. 20). O dogmatismo "consiste na adoção extensiva de argumentos de autoridade na discussão sociológica, ou em certa tendência a discutir ou avaliar fatos através da mera justaposição de textos de autores prestigiosos" (Ramos, 1957, p. 20). O dedutivismo decorre diretamente do dogmatismo, pois "desde que se empresta aos sistemas estrangeiros o caráter de validade absoluta, eles passam a ser tomados como pontos de partida para a explicação dos fatos da vida brasileira" (Ramos, 1957, p. 21).

A característica principal do dedutivismo é a abstração da contingência histórica, é a identificação do presente do nosso país com o presente de países outros em fase superior de desenvolvimento ou, de qualquer modo, de formação histórica diferente da nossa (Ra- 


$$
\text { mos, 1957, p. 21). }
$$

Ressalte-se que o autor considera que houve tempo em que se tentou explicar a evolução do Brasil à luz das leis gerais da evolução sob a ótica positivista, sendo que "atualmente este dedutivismo é perceptível em trabaIhos de sociólogos brasileiros aficionados do marxismo",

Principalmente, quando tentam explicar os nossos problemas políticos e jurídico-sociais, muitos o fazem segundo estudos marxistas aplicados a países estrangeiros, ou segundo aplicação mecânica de categorias marxistas. Procedimento este, diga-se logo, que contraria a essência do marxismo, mas que assinala a força do impacto da situação colonial na psicologia do colonizado (Ramos, 1957, p. 21).

A alienação da Sociologia brasileira decorre de que ela não é, em regra, fruto de esforços tendentes a promover a autodeterminação de nossa sociedade, sendo que o sociólogo brasileiro tem realmente assumido uma atitude perfeitamente equivalente à do estrangeiro que nos olha a partir de seu contexto nacional e em função deste nos interpreta (Ramos, 1957, p, 22). A inautenticidade "é o que resulta de todas as características anteriores", pois, "o trabalho sociológico, em nosso país, não se estriba em genuínas experiências cognitivas", sendo que, "em larga escala, as categorias e os processos que o sociólogo indígena usa são recebidos, por ele, préfabricados" (Ramos, 1957, p. 23).

- O Período de crise e diversificação da Sociologia Brasileira

A emergência, em fins dos anos 50 e início dos anos 60, de uma crítica marxista a ambas as abordagens implicou uma crescente diferenciação paradigmática que foi potencializada, já no decorrer do período de crise e diversificação da Sociologia brasileira, pelos eventos político-culturais dos períodos 1964/1968 e 1969/1974. Essa crítica marxista teve no 
chamado 'Seminário do Capital', desenvolvido por um grupo de intelectuais majoritariamente da USP, seu campo de institucionalização informal e antecipou a experiência do CEBRAP, ao qual muitos dos participantes do Seminário vieram a se integrar; preparou também o caminho para a renovação teórico-metodológica e temática do final dos anos 60 , particularmente em termos da formulação de estudos acerca da dependência (Sorj e Mitre, 1985; Pécaut, 1986). ${ }^{5}$

No bojo da crise social e política brasileira e latino-americana do final dos anos 50 e início da década de 60 (Figura 2), verificou-se o início do período de crise e diversificação da Sociologia brasileira. Este momento foi caracterizado pela crise institucional e profissional da Sociologia e das ciências sociais em geral, sob o efeito das medidas repressivas (cassações, prisões, exílios e desaparecimento) dos regimes autoritários. ${ }^{6} \mathrm{O}$ Golpe de 1964 no Brasil inaugura este ciclo autoritário, também chamado de ciclo do novo autoritarismo, caracterizado pela transformação dos estados desenvolvimentistas-populistas da região em estados burocrático-autoritários, na terminologia proposta por Guillermo O’Donnell (1982), e seguido por uma sucessão de golpes militares, como os ocorridos na Argentina (golpes de 1966 e 1976) e no Uruguai (golpe de 1973).

As dramáticas mortes de Camilo Torres e "Che" Guevara em 1967 pareciam, já então, indicar os limites da alternativa de luta armada em

\footnotetext{
5 Estas questões são analisadas pelo autor em estudos anteriores (Liedke Filho, 1977 e 1990a).

6 Longa é a lista de experiência históricas internacionais e latino-americanas que têm servido de utopias de referência para as forças democrático-progressistas latino-americanas interessadas na construção de uma sociedade democrática, justa e solidária (Figura 2). Recorde-se aqui a Revolução Mexicana de 1910, as Revoluções Russas de 1905 e 1917, a experiência das Brigadas Internacionais na Guerra Civil Espanhola (1936 -1939) , a Revolução Chinesa de 1948, a Independência da Índia em 1947, a luta de libertação nacional do Vietnam (1954 e 1975) e as lutas anticolonialistas pela independência do Congo Belga (1960) e da Argélia (1962).

Destaque especial cabe à Revolução Cubana de 1959, liderada por Fidel Castro e "Che" Guevara e a sua quase imediata proclamação como socialista em 1961, a qual incendiou imaginações na América Latina e colocou os Estados Unidos da América do Norte em alerta ante os riscos de sua reprodução em outros países latino-americanos, levando à criação da Aliança para o Progresso (1961) e ao incentivo e apoio ao ciclo de governos autoritários na região, a partir de meados dos anos sessenta.
} 


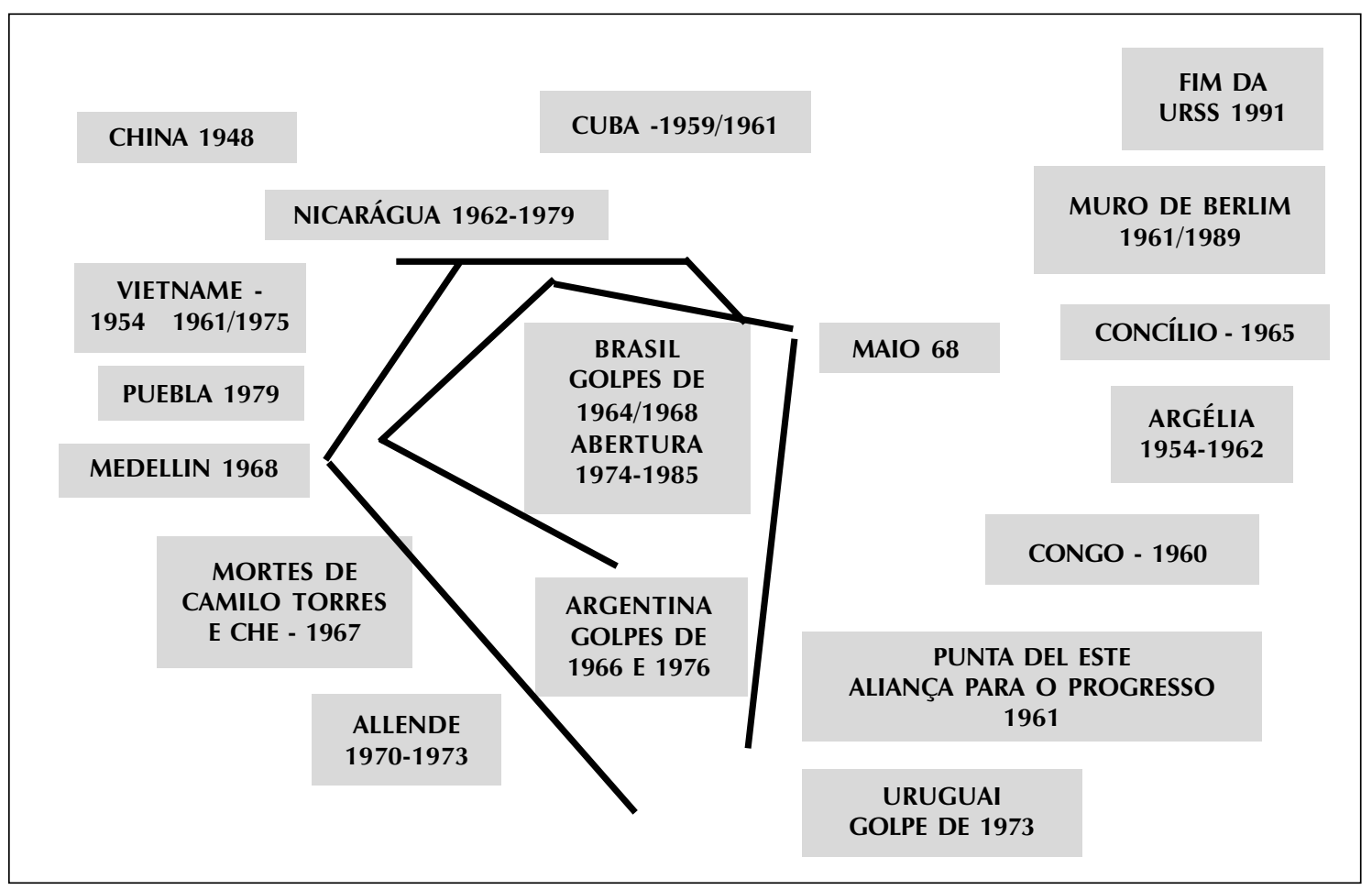

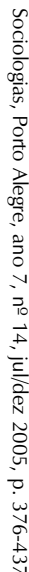

Figura 2 - Contexto mundial 1948-1991. 
países latino-americanos, os quais, ao não serem apreendidos, levaram a uma série de desastres político-militares como, no Brasil, a derrota da guerriIha urbana e a morte dos líderes guerrilheiros Marighella e Lamarca, e a derrota da guerrilha do Araguaia; na Argentina, a derrota dos Montoneros e do ERP e, no Uruguai, a derrota militar dos Tupamaros. O trágico desenlace do governo Allende (1970 - 1973), com o golpe militar liderado por Pinochet, levou à queda da primeira experiência de governo socialista por via eleitoral na América Latina.

Recorde-se também que, ao mesmo tempo, sob as orientações renovadoras do Concílio Vaticano II encerrado em 1965, tem-se a Conferência Episcopal de Medellín (Colômbia) em 1968, a qual assume a Teologia da Libertação como orientação pastoral da Igreja Católica junto aos pobres e oprimidos na América Latina, reafirmada em Puebla em 1979.

O impacto negativo da instauração do regime autoritário sobre a evolução sociológica brasileira está relacionado diretamente com o golpe de 64 e com o "golpe dentro do golpe" de 1968 que tem no Al-5 seu marco principal. O fechamento do ISEB, em 1964, os IPM e as cassações pareciam indicar que as ciências sociais brasileiras estavam entrando em um período recessivo. O fechamento do ISEB em 1964 pelo regime militar e as cassações de cientistas sociais em 1969, assim como o impacto negativo da repressão cultural-educacional aos níveis universitários e das condições de exercício profissional, correspondem plenamente às características gerais da quarta etapa de evolução da Sociologia na América Latina. Todavia, em contraste com a evolução adversa da Sociologia em outros países latino-americanos, particularmente do Cone Sul, sob as condições autoritárias, a Sociologia no Brasil experimentou uma razoável expansão institucional do ensino e da pesquisa.

A tendência a alcançar patamares superiores de institucionalização, que já se vinha verificando desde meados dos anos 50, foi reforçada de- 
pois de 1964, apesar de retrocessos localizados, tais como as cassações e o fechamento do ISEB em 1964, anteriormente referidos, assim como as cassações de 1969 na USP. Esta expansão teve seu centro de gravitação nos cursos de pós-graduação que foram criados e consolidados como centros de ensino e pesquisa, particularmente após a Reforma Universitária de 1969, e teve por contraponto a criação e as atividades de centros privados de pesquisa tais como o CEBRAP, o CEDEC, e o IDESP (Sorj e Mitre, 1985). Sorj e Mitre indicam que:

Nos primeiros anos do regime militar, no período que se estende entre 1964 e 1969, os prognósticos pessimistas pareciam confirmar-se. As cassações de professores universitários logo depois do golpe, e posteriormente, com impacto ainda maior, aquelas que se seguiram ao Al-5, levou a pensar que as ciências sociais entrariam em recesso no Brasil. Neste mesmo período , foi aplicada a reforma universitária, com assessoria americana e contra a vontade da comunidade acadêmica.

Embora importantes, ambos os fenômenos não chegaram a abalar fundamentalmente o futuro desenvolvimento das ciências sociais ainda que certos centros universitários como a USP e UFRJ possam ter sofrido individualmente um impacto maior.

Isto, em primeiro lugar, porque um número importante de cientistas sociais cassados permaneceu no país, inclusive auto-organizados em centros como o CEBRAP, e em segundo lugar, nenhuma instituição chegou a ser fechada ou mesmo esvaziada, permanecendo nos seus cargos a maioria dos quadros docentes. (Sorj e Mitre, 1985, p. 46).

A Reforma Universitária de 1969, introduzindo o sistema departamental e as novas regras e requerimentos para a carreira universitária (incluída a formação em nível de pós-graduação), assim como o novo formato dos programas de pós-graduação, influiu decisivamente no for- 
mato das atividades de pós-graduação e na demanda crescente pelas mesmas. Os dados da Tabela 1 indicam uma crescente institucionalização do ensino de Sociologia em nível de graduação, particularmente no período entre 1954 e 1976, tendo ocorrido uma significativa queda por causas não identificadas, no número de cursos de graduação entre este último ano e o ano de 1978. Correia Dias (1981), analisando os Cursos de Graduação em ciências sociais, por tipo de titulação, indica que em 1978 havia: 56 Licenciaturas; 15 Bacharelados; Bacharelados em Ciências Políticas e Sociais; e 6 cursos organizados segundo o modelo da Escola Livre de Sociologia e Política.

Tabela 1 - Cursos de Graduação em Ciências Sociais Brasil 1936-1978 e HOJE?

\begin{tabular}{|c|c|}
\hline Ano & Número de Cursos \\
\hline 1936 & 2 \\
\hline 1954 & 11 \\
\hline 1968 & 33 \\
\hline 1976 & 83 \\
\hline 1978 & 71 \\
\hline
\end{tabular}

Fontes: CLAPCS (1967) e Correia Dias (1981).

Mesmo o período mais "fechado" do regime autoritário (1968-1974) assistiu a um incremento do número de graduações em Sociologia e ciências sociais, o que deve ter estado associado ao impacto da reforma universitária de 1968, e do processo de "expansão" com "privatização" do ensino superior (Cunha, 1979). Esta "privatização" quanto aos cursos de ciências sociais, evidencia-se nos dados fornecidos pela Tabela 2 os quais indicam que, em 1978, 58,92\% dos cursos estavam vinculados a universidades ou a Faculdades de Filosofia privadas. Ao mesmo tempo, os centros privados de ensino e/ou pesquisa ofereceram uma alternativa às "limita- 
ções" impostas às atividades intelectuais e científicas no âmbito das instituições públicas, particularmente as universidades. Esses centros também ofereceram a oportunidade de exercício profissional a intelectuais que, em função de "cassações", estavam proibidos de exercer atividades em universidades ou agências públicas. Como conseqüência deste processo de crescente institucionalização do ensino e da pesquisa em Sociologia, no início dos anos oitenta, havia cerca de 30.000 sociólogos (bacharéis e ou licenciados em ciências sociais) no Brasil (Dal Rosso, 1981, p. 2).

Tabela 2 - Brasil - Licenciaturas em ciências sociais, por tipo de instituição mantenedora 1976.

\begin{tabular}{|c|c|c|}
\hline TIPO DE INSTITUIÇÃO & No DE INSTITUIÇÕES & $\begin{array}{c}\text { \% DO TOTAL DE } \\
\text { INSTITUIÇÕES }\end{array}$ \\
\hline UNIVERSIDADES & 18 & 32,14 \\
\hline Oficiais & 10 & 17,86 \\
\hline Particulares Confessionais & 6 & 10,71 \\
\hline Particulares & 2 & 3,57 \\
\hline $\begin{array}{c}\text { FACULDADES DE FILOSOFIA OU DE } \\
\text { FILOSOFIA, CIÊNCIAS E LETRAS }\end{array}$ & 25 & 44,64 \\
\hline Instituições Privadas & 23 & 41,07 \\
\hline Faculdades Municipais & 2 & 3,57 \\
\hline TOTAL & 56 & 100 \\
\hline
\end{tabular}

Fonte: Correia Dias (1981).

A crise e a renovação institucional-profissional das ciências sociais no Brasil associaram-se a uma crise e reorientação teórica simultânea e interrelacionada com a crise teórica das ciências sociais na América Latina, a qual foi potenciada e potenciou a crise da "Sociologia Internacional", isto é, a crise mundial das ciências sociais em fins da década de 1960.

Na América Latina, a crise teórico-paradigmática teve como efeito, ao nível da sociologia do desenvolvimento, a formulação de novas abor- 
dagens, quais sejam: Teoria da Dependência, que se distingue em uma versão estagnacionista e uma versão do desenvolvimento dependente, e a abordagem do Novo Autoritarismo que, aceitando os pressupostos da Teoria da Dependência, busca aprofundar suas implicações através da análise da especificidade da dinâmica política em situações dependentes. ${ }^{7}$

Ao mesmo tempo, a preocupação temática com os problemas sociais do Brasil contemporâneo, tais como o modelo econômico-excludente, o modelo político autoritário, os movimentos sociais urbanos e rurais, o novo movimento sindical, a participação e o comportamento político sob a dominância da Teoria da Dependência e a da abordagem do Novo Autoritarismo caracterizam, nos níveis temático e paradigmático, a Sociologia brasileira neste período.

\section{III - Excurso - Sociologia e Cidadania: Florestan Fernandes e Fernando Henrique Cardoso}

A reconstrução comparativa da evolução da obra de dois dos principais sociólogos brasileiros - Florestan Fernandes e Fernando Henrique Cardoso -, empreendida a seguir, permite apreender a dramaticidade dos desafios históricos e teóricos enfrentados por esses sociólogos, bem como as alternativas contrastantes das novas teorizações propostas por eles e das soluções prático-políticas que assumiram na tentativa de cumprir com o duplo papel de sociólogos e de cidadãos.

- Florestan Fernandes e a revolução burguesa brasileira

A evolução das orientações teórico-metodológicas e das preocupações temático-políticas que caracterizam a obra de Florestan Fernandes,

7 Estas questões teórico-políticas serão detalhadas a seguir na parte três, quando da análise das obras de Florestan Fernandes e Fernando Henrique Cardoso. 
permitem a identificação de quatro etapas distintas: Etapa de Formação Intelectual (1941-1952); Etapa da Sociologia numa Era de Revolução Social (1952-1967); Etapa da Reflexão sobre a Revolução Burguesa no Brasil (19671986) e Etapa da Militância-Cidadã (1986-1995). As características principais dessas etapas, apresentadas esquematicamente na Figura 3, serão analisadas a seguir, visando oferecer um guia para a (re) leitura da contribuição intelectual e política de Florestan Fernandes, enquanto sociólogo e cidadão.

A Etapa de Formação Intelectual de Florestan Fernandes estende-se do seu ingresso na Faculdade de Filosofia da Universidade de São Paulo em 1941, até o momento em que assume a Cadeira de Sociologia I em 1953. ${ }^{8}$ Destacam-se, nessa etapa entre os estudos empíricos, os levantamentos acerca do Folclore e da Mudança Social em São Paulo (1976a), A Organização Social dos Tupinambás (redação em 1947 e primeira publicação em 1949; 1963), A Função Social da Guerra na Sociedade Tupinambá (1949; republicado 1970).

Entre os estudos teórico-metodológicos, merecem destaque a introdução, de sua autoria, para a tradução, da Contribuição à Critica da Economia Política de Marx, realizada em 1946, como "tarefa" de sua, então, militância no movimento trotskista, e a monografia acerca da "Concepção de Ciência Política de Karl Mannheim" (In 1974b), redigida em 1946, sob orientação do Professor Emílio Willems, como trabalho da Cadeira de Antropologia da Pós-graduação na Escola Livre de Sociologia e Política de São Paulo.

Destaque cabe também ao texto "O Problema do Método na Investigação Sociológica" (1947, in 1971), no qual se configura a originalidade da formulação teórica inicial da obra de Florestan, a qual imantou a organização da "Escola de Sociologia da USP". 


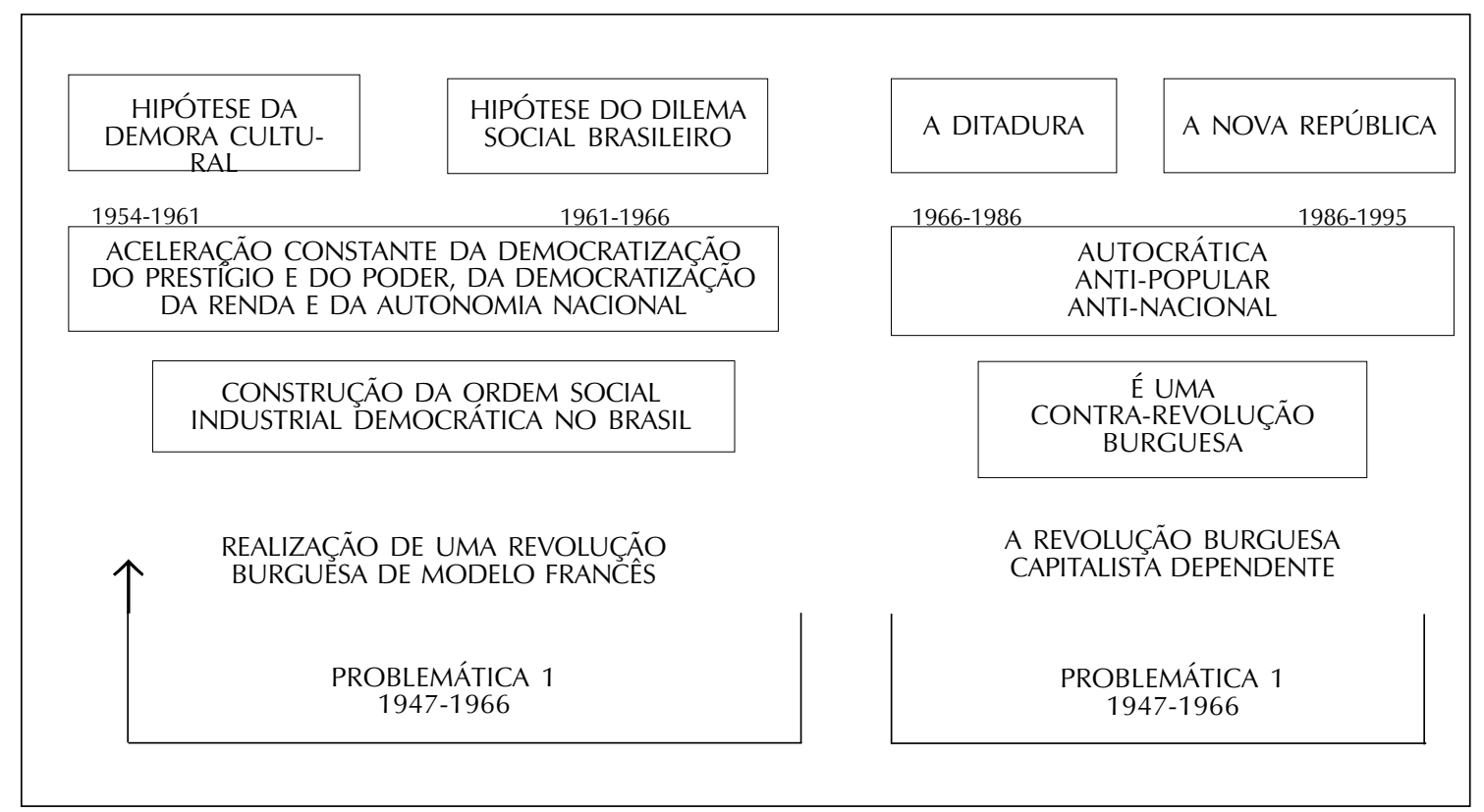

Figura 3 - Florestan Fernandes: concepções da Revolução Burguesa no Brasil. 
Esta formulação se constituiu como uma síntese original entre a problemática básica da concepção de ciência política de Karl Mannheim, conforme explicitada no Capítulo III de Ideologia e Utopia (1952) - quais as possibilidades de construção plena de uma ordem social industrial e democrática, enquanto processo de racionalização - e o método funcionalista, ${ }^{9}$ na tradição de Radcliff Brown, como quadro de referência para a análise da constituição e intervenção racional na sociedade industrial (Liedke Filho, 1977).

Esta problemática está explicitada teoricamente, por exemplo, na reflexão de Florestan Fernandes acerca do "Significado das ciências sociais no Mundo Moderno" (1950, in 1971), na qual argumenta que "de um lado, elas nos abrem perspectivas quase insondáveis de conhecimento e de domínio das forças que operam no meio social em que vivemos. De outro lado, elas poderão contribuir para a formação do novo tipo de homem, exigido pela civilização científica e industrial em desenvolvimento" (1971, p. 300).

Uma segunda etapa da obra de Florestan - Etapa da Sociologia numa Era de Revolução Social ${ }^{10}$ (1952-1965) - tem por base a historicização da problemática original da obra de Florestan Fernandes, a qual passa a ser nucleada na relação entre razão e possibilidades de construção da ordem social, industrial e democrática no Brasil, cabendo, neste processo de intervenção, um papel relevante à Sociologia Aplicada.

Florestan Fernandes, no texto "Desenvolvimento Histórico-Social da Sociologia no Brasil" (1957, in 1977), propôs uma periodização da evolução da Sociologia no Brasil tendo por base o objetivo dominante da produção de conhecimentos sociológicos, o que permite compreender o signi-

9 Ver "Introdução" de Folclore e Mudança Social no Brasil (1976), em que Florestan descreve seu aprendizado do funcionalismo. 10 Ver A Sociologia em Uma Era de Revolução Social (1976). 
ficado que ele atribuía à Sociologia e ao seu próprio trabalho intelectual nesta etapa.

Um primeiro período da Sociologia no Brasil foi marcado pelo autodidatismo e se iniciou já no terceiro quartel do século XIX, correspondendo à fase de desagregação da ordem social escravocrata, sendo caracterizado pela exploração de conhecimentos sociológicos como recurso parcial de interpretação. A intenção principal não era fazer investigação sociológica propriamente dita, mas considerar fatores sociais na análise de certas relações como, por exemplo, as conexões entre o Direito e a Sociologia, a literatura e o contexto social, o Estado e a organização social. Um segundo período teve início em princípios do século, quando a Sociologia frutifica, tanto sob a forma de análise histórico-geográfica e sociológica do presente quanto sob a inspiração de um modelo mais complexo de análise histórico-pragmática, em que a interpretação do presente se associava a disposições de intervenção racional no complexo social. Finalmente, um terceiro período, o qual, embora com raízes no segundo quartel deste século só se configura plenamente no pós-guerra - época de redação dessa análise de Florestan - tem por característica dominante a preocupação de subordinar o labor intelectual no estudo dos fenômenos sociais aos padrões de trabalho científico sistemático. Esta intenção se revela tanto nas obras de investigação empírico-indutiva de reconstrução histórica ou de campo quanto nos ensaios de sistematização teórica.

Em 1952, Florestan Fernandes assumiu a Cadeira de Sociologia I, em substituição a Roger Bastide que retornava então à Europa, e deu início à organização de um grupo de colaboradores, constituído inicialmente por Fernando Henrique Cardoso, Octavio lanni e Renato Jardim Moreira, originando a "Escola de Sociologia da USP". Por "Escola de Sociologia da USP" ou "Escola de Sociologia de Florestan Fernandes"11 entende-se o

11 Acerca da história do grupo cientistas sociais em questão, ver Fernandes, F.A Sociologia no Brasil (1977), capítulos 7 e 8, e Liedke Filho (1977 e 1990a). 
grupo de cientistas sociais que trabalharam ligados a este sociólogo no período de 1954 a 1969, na antiga Faculdade de Filosofia da USP, desenvolvendo uma série de projetos de pesquisa comuns, abrangendo temas referentes (1) às relações raciais no Brasil, ${ }^{12}$ (2) à empresa industrial em São Paulo e (3) à análise sociológica do desenvolvimento no Brasil,, ${ }^{13}$ na "aventura comum de vincular a investigação sociológica à transformação da sociedade brasileira" (1975a, p. 5).

A reflexão acerca da Sociologia Aplicada ocupa lugar de destaque na produção intelectual de Florestan Fernandes nesta etapa, sendo a mesma concebida como a "análise dos efeitos disnômicos da vida social e das condições previsíveis de intervenção racional no controle das situações em que elas emergem socialmente", sendo uma das exigências fundamentais da mesma, que seja uma análise do presente (1971, p. 151).

São desta etapa da obra de Florestan, expressando suas bases teórico-metodológicas, os textos "O Método de Interpretação Funcionalista em Sociologia" (Tese de Livre-Docência à Cadeira de Sociologia I, defendida em 1953); "O Problema da Indução na Sociologia" (1954) e "A Reconstrução da Realidade nas ciências sociais" (1957), publicados na coletânea Fundamentos Empíricos da Explicação Sociológica (Fernandes,1980a).

Na nova "Introdução" a Mudanças Sociais no Brasil (1974a), Florestan aponta retrospectivamente que a problemática básica de sua obra nesta etapa poderia ser repensada ou reformulada nos seguintes termos: a sociedade brasileira (no limite, a burguesia brasileira) teria condições de fazer uma Revolução Burguesa nacional-democrática-popular, clássica, de estilo francês?

\footnotetext{
12 Ver o projeto e os resultados da pesquisa que originaram esta linha de investigação, em Bastide, R. e Fernandes, Brancos e Negros em São Paulo, São Paulo: Companhia Ed. Nacional, 1971, 3a. ed.; Cardoso, F He lanni, O. Cor e Mobilidade Social em Florianópolis, São Paulo, Cia Editora Nacional, 1960; Cardoso, F H Capitalismo e Escravidão no Brasil Meridional, São Paulo: DIFEL, 1962: lanni O. As Metamorfoses do Escravo, São Paulo, DIFEL, 1962; Fernandes, F O Negro no Mundo dos Brancos, São Paulo: DIFEL, 1972, Fernandes F. A Integração do Negro na Sociedade de Classes; São Paulo: Dominus Editora e Editora da USP, 1965.
}

13 Ver os projetos 2 e 3 em Fernandes, 1974a e 1976b. 
Sugerimos em estudo anterior (Liedke Filho, 1977) que essa etapa da obra de Florestan divide-se em dois subperíodos, caracterizados pela vigência de hipóteses-respostas diferentes à mesma questão de fundo: a Hipótese da Demora Cultural (1954-1959) e a Hipótese do Dilema Social Brasileiro (1959-1965).

A Hipótese da Demora Cultural presente em textos como "Existe uma Crise da Democracia no Brasil?" (Fernandes, 1954, in 1974a) e "Obstáculos Extra-Econômicos à Industrialização" (Fernandes,1959 in 1974a), ...consiste na presunção de que, quando não é homogêneo o ritmo da mudança das diversas esferas culturais e institucionais de uma sociedade, umas esferas podem se transformar com mais rapidez do que outras, introduzindo-se um desequilíbrio variável na integração delas entre si. Quando isto ocorre, é óbvio que no período de transição se produzem atritos e tensões resultantes das próprias condições de mudança social. As expectativas de comportamento antigas e as recém-formadas coexistem, inevitavelmente, durante algum tempo, criando friç̧ões nos ajustamentos dos indivíduos a situações que são por elas reguladas socialmente (Fernandes, 1974a, p. 101).

Em "Existe uma Crise da Democracia no Brasil?" (1954, in 1974a), buscando responder por que a construção da democracia no Brasil era então, em seu entender, um processo incipiente, Florestan aponta a possibilidade de emergência de disnomias (irracionalidades) em setores da vida social, estereotipados em termos de tensões entre padrões recorrentes tradicionais de ação e padrões racionais emergentes de institucionalização e ação.

Neste texto, tem-se, de um lado, a análise do momento brasileiro de então, isto, é, tem-se uma crítica do "atual regime" (assim como o do 
Estado Novo que o antecedeu) e, de outro, as dimensões abrangidas por esta crítica - partidos e demais instituições políticas (campo estrutural da política), anarquia e oportunismo (características do campo funcional da política) - são caracterizadas como fenômenos particulares de Demora Cultural, "para os quais contribuiu a falta de um elevado padrão de educação popular no Brasil", produto da antinomia entre necessidade de educar as massas populares e incapacidade dos governos em atender efetivamente essa necessidade - compreendida como um dos focos mais ativos da instabilidade do regime republicano. Ou seja, o problema da carência educacional das massas e da necessidade de superá-las, como campo estratégico para o confronto da Demora Cultural, adquire uma importância analítica crescente. Neste contexto, Florestan sustenta que,

...toda a argumentação desenrolada tenta mostrar que um dos fatores que prejudicam o desenvolvimento da democracia no Brasil é a persistência de uma mentalidade política arcaica, inadequada para promover ajustamentos dinâmicos não só a situações que se alteram socialmente, mas que estão em fluxo contínuo no presente. A contribuição que a educação sistemática pode oferecer para alterar semelhante mentalidade exprime, naturalmente, as tarefas políticas que ela pode preencher em uma esfera neutra (1974a, p. 114).

E a partir destes marcos interpretativos, efetivou-se o envolvimento de Florestan Fernandes na Campanha em Defesa da Escola Pública, ${ }^{14}$ tanto em termos da produção de análises da questão como da participação efetiva na Campanha, através de conferências e comícios públicos e de contatos com deputados e senadores, nos momentos que antecederam a votação, pelo Congresso, da Lei de Diretrizes e Bases da Educação. Esse 
envolvimento e a frustração quanto aos rumos tomados pelos legisladores e o próprio Executivo, chefiado já então (1961) por João Goulart, levaram a uma mudança da hipótese orientadora da obra de Florestan, enquanto resposta à problemática básica das possibilidades de constituição de uma ordem racional, industrial e democrática no Brasil, passando a vigorar a Hipótese do Dilema Social Brasileiro, em substituição à Hipótese da Demora Cultural. ${ }^{15}$

O Dilema Social Brasileiro consiste "numa resistência residual superintensa à mudança social, que assume proporções e conseqüências sociopáticas" (1976b, p. 211). Trata-se de "um tipo de inconsistência estrutural e dinâmica que nasce da oposição entre o comportamento social concreto e os valores morais básicos de determinada ordem social" (1976b, p. 208), comportamento este das camadas privilegiadas econômica-social e politicamente.

[O] dilema social brasileiro caracteriza-se como um apego sociopático ao passado, que poderá ter conseqüências funestas. Ostenta-se uma adesão aparentemente leal e faminta ao progresso. Professa-se, porém, uma política de conservantismo cultural sistemático. Os assuntos de importância vital para a coletividade são encarados e resolvidos à luz de critérios que possuíam eficácia no antigo regime, ou seja, há três quartos de século. Enquanto isso, as tensões se acumulam e os problemas se agravam, abrindo sombrias perspectivas para o futuro da Nação. É patente que os adeptos dessa política estão cultivando, paradoxalmente, uma gigantesca revolução social, altamente sangrenta e destrutiva em sua fase de explosão (1962, in 1976b, p. 212).

15 Ver a autocrítica de Florestan quanto à Hipótese da Demora Cultural em "Reflexões sobre as Mudanças Sociais no Brasil", in 1976b: 210. 
Uma terceira etapa da obra de Florestan Fernandes - Etapa da Reflexão sobre a Revolução Burguesa no Brasil - inicia-se sob o impacto do movimento de 1964, quando se realiza uma ruptura radical com a problemática até então vigente na sua produção intelectual.

A dignidade intelectual de Florestan Fernandes nos dramáticos momentos que se seguiram a 1964, está registrada em seu discurso de paraninfo da turma da Faculdade de Filosofia, Ciências e Letras de 1964, intitulado "A Revolução Brasileira e os Intelectuais" (1965, in 1969), e, particularmente, em sua "Autodefesa", carta enviada ao Encarregado do Inquérito Policial-Militar junto à Faculdade de Filosofia, Ciências e Letras da USP e que precedeu sua prisão por três dias em setembro de 1964, carta esta publicada como "Apêndice" ao texto "Em Busca de Uma Sociologia Crítica e Militante" (1977).

"Sociedade de Classes e Subdesenvolvimento" (1967, in 1969) é o texto-marco dessa ruptura, enquanto instauração da problemática do subdesenvolvimento como forma específica de realização do capitalismo mundial, a qual se apresenta como uma forma particular de Revolução Burguesa, despojada de qualquer impulso construtivo e revolucionário. $\mathrm{O}$ referido texto, que dá o nome à coletânea em que foi publicado, distancia-se profundamente dos demais textos desta, os quais, redigidos entre 1965 e 1967, ainda se encontram dentro dos marcos teóricos da problemática anterior da produção de Florestan Fernandes, tendo o conceito de Dilema Social como conceito explicativo principal. Ressalte-se, todavia, que o caráter particular da Revolução Burguesa no Brasil, a partir da formação histórica da sociedade brasileira, adquire importância crescente ao longo desses textos redigidos entre 1965 e 1967, vindo a culminar na referida ruptura. ${ }^{16}$

\footnotetext{
16 Ver especialmente "A dinâmica da mudança sócio-cultural no Brasil" (1965, in 1969), texto em que a "irracionalidade do comportamento conservador", é objeto de minuciosa análise.
} 
Um dos pontos que merecem destaque especial em "Sociedade de Classe e Subdesenvolvimento" (in 1969), além da original síntese entre conceitos de Marx, Weber e Durkheim para a explicação macrossociológica do subdesenvolvimento econômico, da análise do significado da articulação de estruturas econômicas heterogêneas no sistema econômico nacional brasileiro e da análise da constituição, funcionamento e evolução do regime de classe no Brasil, é a formulação do conceito de "racionalidade econômica possível em circuito de indeterminação", dada a partir das tendências da referida heterogeneidade estrutural. Referindo-se à ação das classes dominantes, Fernandes afirma que

Elas vêem o capitalismo e suas exigências sociais, culturais e políticas do ângulo do capitalismo dependente. Ao fazer sua revolução, fazem-na na escala das realizações e das ambições fomentadas pelo capitalismo dependente. Nenhuma outra classe social as contesta com probabilidade de êxito. De qualquer modo, condenam-se a protagonizarem a história como uma eterna façanha de dependência. Para que elas se ergam acima dessa medida, elas precisam ser negadas e arrastadas por outras classes. Enfim, precisam ser compelidas a pensar e a transformar o mundo de uma perspectiva universal (1969, p. 103).

Neste período, cabe destaque especial ao estudo $A$ Integração do Negro na Sociedade de Classes (1965), estudo escrito entre 1963 e 1964, dentro dos marcos teóricos então vigentes na produção deste autor, sendo a expressão máxima da tensão teórica referida, entre uma crescente centralidade do caráter específico da Revolução Burguesa em condições de dependência e a vigência ainda da Hipótese de Dilema Social. Este estudo concluía que, no Brasil,

O dilema racial brasileiro (...) se caracteriza pela forma fragmentária, unilateral, e incompleta com que lo regime de classes sociais] consegue abranger, coordenar e 
regulamentar as relações raciais. Estas não são totalmente absorvidas e neutralizadas, desaparecendo atrás das relações de classes. Mas sobrepõem-se a elas, mesmo onde e quando as contrariam, como se o sistema de ajustamentos e de controles sociais da sociedade de classes não contivesse recursos para absorvê-las e regulá-las socialmente (1965, Vol. II, p. 391).

A produção posterior de Florestan Fernandes busca explicitar o caráter autocrático da Revolução Burguesa em situações de capitalismo dependente no contexto do sistema capitalista monopolista mundial, sendo interessante ressaltar que os capítulos constitutivos da primeira e segunda partes de A Revolução Burguesa no Brasil (1975a) foram redigidos em 1966 e somente publicados em 1975, donde a profunda distância entre esses capítulos elaborados ainda dentro dos marcos teóricos da Hipótese do Dilema Social Brasileiro e os capítulos da Parte Terceira do referido livro, que foram elaborados em 1973/74, enfatizando o caráter autocrático, a "força selvagem" e a "debilidade crônica" da Revolução Burguesa sob o capitalismo dependente.

A revolução burguesa brasileira, caso particular da Revolução Burguesa em condições de subdesenvolvimento, ou melhor, de nova dependência, é caracteristicamente antidemocrática e anti-popular. A hipótese básica passa a ser a de que as condições histórico-sociais características do desenvolvimento capitalista dependente (da nova dependência, mais especificamente) determinam que a dominação burguesa se dê claramente de forma autocrática. Isto é, acumulação de capital ao nível econômico a todo custo (social geral) e democracia restrita aos próprios membros da classe burguesa e a alguns "cidadãos" mais privilegiados, são as duas faces deste domínio de classe.

O sentimento pessoal de Florestan Fernandes após a sua cassação da Universidade de São Paulo em 1969, a radicalização da sua avaliação 
política da situação brasileira e a dor do exílio em Toronto transparecem no texto "A Geração Perdida", considerado como uma "última contribuição que um dos membros dessa geração perdida pode dar para chamar aos espíritos à razão e para dizer o que pretendíamos, em nome de uma aspiração legítima e tardia de autonomia cultural" (1977, p. 215).

O retorno de Florestan Fernandes ao Brasil, em 1973, foi marcado inicialmente por um isolamento que, aos poucos, foi sendo superado pela colaboração crescente com movimentos sociais então emergentes e pelo convite feito, em 1978, para lecionar na Pós-graduação de ciências sociais da Pontifícia Universidade Católica de São Paulo, onde ministrou cursos teóricos e cursos acerca da Revolução Russa e da Revolução Cubana.

A entrevista "Sobre o Trabalho Teórico" (1975b), publicada na Revista Trans/Form/Ação e o texto "Em Busca de uma Sociologia Crítica e Militante" (1976, in 1977) revelam o estado de espírito, a crítica permanente à dominação burguesa no Brasil e a renovação das esperanças no socialismo e em uma contribuição positiva da sociologia aos grupos divergentes e aos movimentos de contestação daquela dominação.

Durante este período, a crítica ao caráter elitista e antipopular da transição política brasileira, consubstanciada em estudos, comunicações e artigos de jornais, foi reunida em coletâneas como Circuito Fechado (1976c), Brasil em Compasso de Espera (1980b) e A Ditadura em Questão (1982).

Em maio de 1986, Florestan Fernandes foi o homenageado da 1 . Jornada de ciências sociais da UNESP - Campus de Marília, estando os trabalhos apresentados nessa ocasião, reunidos na coletânea O Saber Militante - Ensaios sobre Florestan Fernandes, organizada por Maria Angela D'Incao (1987) os quais, além de depoimentos de amigos, de colegas e ex-alunos, abordam múltiplas facetas da contribuição intelectual de Florestan às ciências sociais e ao conhecimento da sociedade brasileira. Neste mesmo ano, Florestan Fernandes retorna à Faculdade de Filosofia da Universidade de São Paulo. 
Ainda em 1986, com a aceitação do convite formulado pelo Partido dos Trabalhadores para concorrer à Câmara dos Deputados, tem início uma quarta etapa - Etapa da Militância-Cidadã, em que, junto com a crítica ao jogo político das elites para a manutenção de seus privilégios durante a fase Constituinte, à Nova República e à eleição presidencial de 1989, vieram a ocupar lugar de destaque as intervenções de Florestan Fernandes como Deputado Federal Constituinte e membro da Comissão de Educação, a favor de uma educação verdadeiramente popular e democrática, tendo proposto a lei que estabelece um percentual para a educação e ciência.

Nessa etapa, destacam-se os livros Que Tipo de República? (1986), O Processo Constituinte (1988), Florestan Fernandes - Pensamento e Ação O PT e os Rumos do Socialismo (1989), A transição prolongada (1990), Democracia e Desenvolvimento - A Transformação da Periferia e o Capitalismo Monopolista na Era Atual (1994) e Tensões na Educação (1995).

- Fernando Henrique Cardoso - dependência, autoritarismo e democracia na América Latina

A produção intelectual de Fernando Henrique Cardoso abrange uma variada gama de temas teóricos e históricos em ciências sociais, tais como: relações raciais no Brasil; empresariado e desenvolvimento econômico no Brasil; dependência e classes sociais na América Latina; autoritarismo e possibilidades da redemocratização no Brasil. Este artigo apresenta os principais momentos da história intelectual de Fernando Henrique, enfocando particularmente suas idéias acerca do Brasil contemporâneo.

Propõe-se aqui que o conjunto dos estudos de Fernando Henrique Cardoso sobre o Brasil contemporâneo, divide-se em quatro temas-momentos: o estudo da sociedade escravocrata brasileira e das relações raciais no Brasil (1955-1961); a reflexão sobre o desenvolvimentismo brasileiro (1961-1963); a análise da dependência estrutural da sociedade brasileira no contexto da dependência latino-americana (1965-1972); e o modelo 
político autoritário brasileiro e as possibilidades e tarefas da redemocratização (1971-).

Fernando Henrique Cardoso, nascido em 1931, formou-se em ciências sociais na Universidade de São Paulo em 1952, tendo sido aluno, entre outros, do sociólogo francês Roger Bastide, de Antonio Candido e de Florestan Fernandes. Ainda durante a Licenciatura, Cardoso iniciou sua carreira docente, lecionando História Econômica da Europa na Faculdade de Economia da USP. Em 1952, Cardoso transferiu-se para a Cátedra de Sociologia I dirigida por Bastide, passando a trabalhar com seu assistente Florestan Fernandes, concluindo seu mestrado em 1953, sob a orientação deste.

Em 1954, como mencionado anteriormente, Florestan Fernandes assumiu a Cátedra de Sociologia I, passando a organizar um grupo de pesquisadores que veio a ser conhecido como a "Escola de Sociologia da USP" ou "Escola de Sociologia de Florestan Fernandes". Constituído inicialmente por Florestan Fernandes, Fernando Henrique, Octávio lanni e Renato Jardim, esse grupo veio a incorporar outros cientistas sociais como Marialice Foracchi, Luiz Pereira e Gabriel Cohn. No período de 1954 a 1969, a "Escola de Sociologia da USP", desenvolveu pesquisas sobre relações raciais no Brasil, a empresa industrial em São Paulo e sobre o processo de desenvolvimento brasileiro.

Paralelamente às pesquisas da "Escola", ocorreu no final dos anos cinqüenta, a constituição de um grupo de estudos dedicado à análise de O Capital de Marx. Esse grupo, conhecido como o "Seminário do Capital" incluiu entre outros, Cardoso, Ianni, Fernando Novais, Bento Prado, José Giannotti, Paul Singer e Roberto Schwarz.

No período de 1955 a 1960, Cardoso e lanni realizam, com a colaboração parcial de Renato Jardim, um levantamento de dados sobre a situação social dos negros no Brasil Meridional, tanto no passado como no presente. Como resultados desta investigação são publicados os livros Cor e Mobilidade Social em Florianópolis (1961), de Cardoso e lanni, Capitalismo e Escravidão no Brasil Meridional (1962) de Cardoso e As Metamorfoses do 
Escravo (1962) de lanni.

A obra histórico-sociológica Capitalismo e Escravidão no Brasil Meridional (1962), apresentada por Cardoso como tese de doutorado, analisa o sistema escravista no Rio Grande do Sul enquanto totalidade social concreta que resultou da interação entre senhores e escravos na sociedade gaúcha, implicando a dupla alienação de senhores e escravos. Essa obra foi redigida sob a influência da metodologia dialética e do conceito de práxis-projeto propostos por J. P. Sartre em A Questão de Método (1967), associados por Cardoso a elementos teóricos extraídos da obra de Marx, particularmente as teorias da alienação e da mais-valia. Cardoso propunha que o problema teórico central para qualificar a sociedade capitalistaescravista brasileira era a relação entre a forma capitalista (mercantil) do sistema econômico mundial e a base escravista das relações de produção. Cardoso sugere o emprego dos conceitos de patrimonialismo senhorial e de casta escrava, redefinidos sob a égide do capitalismo mercantil, para explicar esta particularização do capitalismo mercantil-escravista, onde o capital variável (força de trabalho) é fixo (escravo), não havendo salário.

A partir de 1959, buscando contribuir para a compreensão do Brasil contemporâneo, a "Escola da USP" passa a pesquisar o desenvolvimento brasileiro, enfocando temas como o Estado e o desenvolvimento econômico, a qualificação da mão de obra, a mobilização do operariado, as disparidades regionais do desenvolvimento e a estrutura da indústria paulista. Dentro deste esforço coletivo, Fernando Henrique Cardoso passa a dedicar-se à reflexão sobre o desenvolvimentismo brasileiro, tema central do segundo momento de sua obra.

Em sua tese de livre-docência, defendida em novembro de 1963, Empresário Industrial e Desenvolvimento Econômico no Brasil, Cardoso discute a questão central do período histórico desenvolvimentista - teria a burguesia nacional intenção e condições de realizar um projeto de desenvolvimento nacional, democrático-popular?

Nessa obra, Cardoso aponta que o processo subdesenvolvimentodesenvolvimento, enquanto "movimento social", implica em que se rete- 
nha que:

entre um movimento e outro da história de uma sociedade, há a mediação de uma luta que reflete a tensão entre interesses e objetivos sociais diversos num duplo sentido: altera-se a posição da sociedade particular no conjunto das sociedades e modifica-se internamente a posição das camadas da sociedade que se está desenvolvendo (Cardoso, 1964, p. 70-71).

Os resultados da pesquisa desenvolvida entre 1961 e 1963 acerca das elites empresariais permitiram a Cardoso sustentar teses contrárias à interpretação do desenvolvimentismo, então compartilhada tanto pelo ISEB (Instituto Superior de Estudos Brasileiros) como por setores marxistas. Cardoso apontava que (1) não foi a burguesia industrial a responsável primeira pela elaboração do projeto nacional-desenvolvimentista, mas sim setores tecnocráticos do Estado que, com a chancela das oligarquias, buscavam atender as reivindicações das massas populares urbanas nascentes; (2) quando a burguesia industrial pôde e buscou ter um "controle da situação", ela redefiniu o projeto vigente, enfatizando o desenvolvimentismo não-nacionalista, facilitando o ingresso de capitais internacionais e marchando para um "subcapitalismo". Destaque-se que a apreensão destas tendências históricas, quando o nacionalismo-desenvolvimentista ainda dominava a cena política nacional, veio a revelar-se estratégica como fundamento para as análises desenvolvidas posteriormente por Cardoso: a da dependência latino-americana e do pós-64 brasileiro.

Em 1964, receoso da possibilidade de sua prisão, Cardoso se autoexilou em Santiago do Chile, onde permaneceu até 1967, trabalhando na equipe do economista argentino Raul Prebish, diretor da Comissão Econômica para a América Latina-CEPAL, e lecionando na Faculdade Latino Americana de ciências sociais. Inicia-se então, um terceiro momento da produção intelectual de Cardoso, voltada para a comparação entre o Brasil con- 
temporâneo e outras sociedades latino-americanas.

Em 1966 elabora, em parceria com o historiador Enzo Faletto, o livro Desenvolvimento e Dependência na América Latina (1973), que veio a alcançar ampla repercussão internacional, tendo sido publicado em diversos idiomas. Desenvolvimento e Dependência na América Latina propõe um quadro teórico-metodológico para a análise das condições específicas da situação latino-americana e do tipo de integração social das classes e grupos como condicionantes principais do processo de desenvolvimento.

A principal proposição metodológica adiantada pelos autores é de que a análise integrada do processo de desenvolvimento nacional "consiste em determinar as vinculações econômicas e político-sociais que se dão no âmbito da nação", nestes termos: "objetiva-se apreender o verdadeiro caráter da dependência - um tipo específico de relação entre as classes e grupos que implica uma situação de domínio que mantém estruturalmente a vinculação econômica com o exterior" (Cardoso e Faletto, 1973, p. 31).

A análise integrada do processo de desenvolvimento nacional enfatiza que

as alianças dos grupos e forças sociais internas estão afetadas pelo tipo e intensidade das mudanças, e estas dependem, em parte, do modo de vinculação das economias nacionais ao mercado mundial; a articulação dos grupos econômicos nacionais com os grupos e forças externos realiza-se distintamente e com conseqüências diferentes, antes e depois de começar um processo de desenvolvimento. O sistema interno de alianças políticas altera-se, além disso, muitas vezes em conseqüência das alianças existentes no plano internacional (Cardoso e Faletto, 1973, p. 29). 
Neste contexto, torna-se importante reter também a distinção entre os conceitos de Dependência, de Subdesenvolvimento, e de "Centro e Periferia".

A noção de 'dependência' alude diretamente às condições de existência e funcionamento do sistema econômico e do sistema político, mostrando as vinculações entre ambos, tanto no que se refere ao plano interno dos países como ao externo.

A noção de 'subdesenvolvimento' caracteriza um estado ou grau de diferenciação do sistema produtivo, apesar de que isso implique algumas conseqüências sociais sem acentuar os pontos de controle das decisões de produção e consumo, seja internamente (socialismo, capitalismo, etc.) ou externamente (colonialismo, periferia de mercado mundial, etc.). As noções de "Centro" e de "Periferia", por seu lado, destacam as funções que cabem às economias subdesenvolvidas no mercado mundial, sem levar em conta os fatores políticos-sociais implicados na situação de dependência (Cardoso e Faletto, 1973, p. 26).

A discussão comparativa da crise sociopolítica das sociedades latinoamericanas, no período de "expansão para fora", tendo por referência os conceitos de "situações de controle nacional do sistema produtivo" (Argentina, Brasil, Uruguai e Colômbia) versus "situações de economia de enclave" (México, Bolívia, Venezuela, Chile, Peru e América Central), representou uma renovação interpretativa da história latino-americana. Ao mesmo tempo, propunha-se a necessidade de apreender "o novo caráter da dependência" - a internacionalização do mercado - através da abertura dos mercados internos ao controle externo, via ingresso de capitais estrangeiros.

É interessante destacar que esta hipótese já apontava para uma interpretação antiestagnacionista, rejeitando a tese da inviabilidade do desenvol- 
vimento capitalista em condições de dependência, tese esta que orientou, no Brasil, até o início dos anos setenta, a tática de resistência política antiautoritária proposta por setores nacionalistas e também por amplos setores da esquerda socialista, incluindo várias organizações armadas.

Após lecionar em Nanterre na França, nos anos de 1967 e 1968, Cardoso retorna ao Brasil, candidatando-se, com sucesso, à catedra de Ciência Política da Universidade de São Paulo. Em 1969, no auge da onda repressiva que se seguiu à promulgação do Ato Institucional no 5 , ocorrem cassações de cientistas e pesquisadores de universidades brasileiras, estando Fernando Henrique Cardoso, Florestan Fernandes, Paula Beiguelman, Octávio lanni e Paul Singer entre os cientistas aposentados compulsoriamente da Universidade de São Paulo.

Ainda em 1969, Cardoso participa, em São Paulo, junto com outros cientistas e intelectuais como Cândido Procópio Camargo, Elza Berquó, Paul Singer e José Gianotti, da fundação do CEBRAP - Centro Brasileiro de Análise e Planejamento. Esta entidade ocupou papel de destaque na vida intelectual e política brasileira ao longo do processo de redemocratização. Entre as obras elaboradas pelos pesquisadores do CEBRAP, merece destaque o livro São Paulo 1975: Crescimento e Pobreza, redigido a pedido da Comissão Pastoral de Justiça e Paz de São Paulo, para leitura e reflexão por comunidades de base.

No início dos anos setenta inicia-se um quarto momento da produção intelectual de Fernando Henrique sobre o Brasil contemporâneo, centrando-se na análise do modelo econômico-político do regime pós-64 e das possibilidades de uma real democratização da vida social brasileira. Em 1976, Cardoso publica a coletânea Autoritarismo e Democratização, em que substitui o conceito de internacionalização do mercado interno pelo de capitalismo dependente-associado, e propôs, para a compreensão do Brasil pós-64, o conceito de capitalismo dependente-associado, com base na aliança entre empresas estatais e em capitais internacionais, os quais têm por parceira menor a burguesia local, que "não deixou de existir" 
(Cardoso, 1976, p. 34).

Nos artigos constantes dessa coletânea, Cardoso critica tanto os apologetas do "milagre brasileiro", como "as novas teses equivocadas sobre a América Latina" (Quadro 3) que, à esquerda, postulam como necessária a relação entre dependência, ditadura e superexploração da mão de obra, supondo que "os frutos do crescimento derivam quase só do suor dos trabalhadores, do baixo nível de remuneração, da marginalização crescente de uma parcela da população, do sub-emprego, etc." (Cardoso, 1976, p. 31). Segundo Cardoso, esquecem-se os que se apegam a este estilo de interpretação que o capital, se bem que expresse diretamente uma relação social de exploração, implica, quando o capitalismo avança, tanto o uso de tecnologias como a produção de excedentes que dão vida e dinamismo a setores não produtivos da sociedade. Ao mesmo tempo, esquecem também que o nervo do capitalismo avançado se baseia na extração da mais-valia relativa (decorrente do progresso técnico e não da superexploração da jornada de trabalho) e na competição (embora oligopólica) entre produtores.

Quadro 3 - Fernando Henrique Cardoso - As novas teses equivocadas sobre a América Latina.

1 - O desenvolvimento capitalista na periferia é inviável.

2 - O capitalismo dependente está baseado na exploração extensiva da mão de obre e preso na necessidade de sub-remunerar o trabaIho.

3 - As burguesias locais deixaram de existir como força social ativa. 4 - A penetração das empresas multinacionais leva os estados nacionais a uma política expansionista.

5 - O caminho político do continente está frente a uma encruzilhada: "socialismo ou fascismo". 
Nestes termos, Cardoso considera que, embora o caráter excludente, regressivo da distribuição de renda do "milagre brasileiro", tenha propiciado o consumo conspícuo, luxuoso, das camadas de altas rendas, favorecendo o próprio "milagre", a concentração de renda não é essencial ao capitalismo dependente-associado. Se houver vontade política, o desenvolvimento capitalista associado pode coexistir com algum tipo de distribuição crescente da renda, em outras palavras, com algum tipo de democracia social.

Em conjunto com esta tese, Cardoso reafirma sistematicamente que o desenvolvimento capitalista-dependente não implica, não requer autoritarismo político, ou como alguns como Theotonio dos Santos (1972) postularam fascismo (Figura 4). Cardoso levanta a possibilidade de formas democráticas de vida social, ainda que em condições de dependência, bem como a necessidade da reflexão e da luta social pela "democratização substantiva", através da "reativação da sociedade civil" brasileira. Estes temas vieram a ser incorporados no programa do único partido de oposição legal de então - o Movimento Democrático Brasileiro - para a campanha de 1974, elaborado por Paul Singer, Francisco de Oliveira e Fernando Henrique Cardoso, a convite de Fernando Gasparian e Ulisses Guimarães.

Concebida como alternativa política ao autoritarismo do modelo pós64, a noção de "reativação da sociedade civil" (Cardoso, 1976) consiste em ir tecendo os fios da sociedade civil, de tal forma que ela possa expressar-se na ordem política e possa contrabalançar o Estado, tornando-se parte da realidade política da Nação. Tratar-se-ia de ir fazendo com que as associações profissionais, os sindicatos, as igrejas, os grêmios estudantis, os círculos de estudos e debates, os movimentos sociais, em suma, expusessem de público seus problemas, propondo soluções e entrando em conflitos construtivos para o país. Neste contexto, seria preciso não esquecer que, dentro do aparelho de Estado, também seria preciso legitimar as divergências construtivas e eliminar as tendências favoráveis à uniformidade pseudo-consensual. 


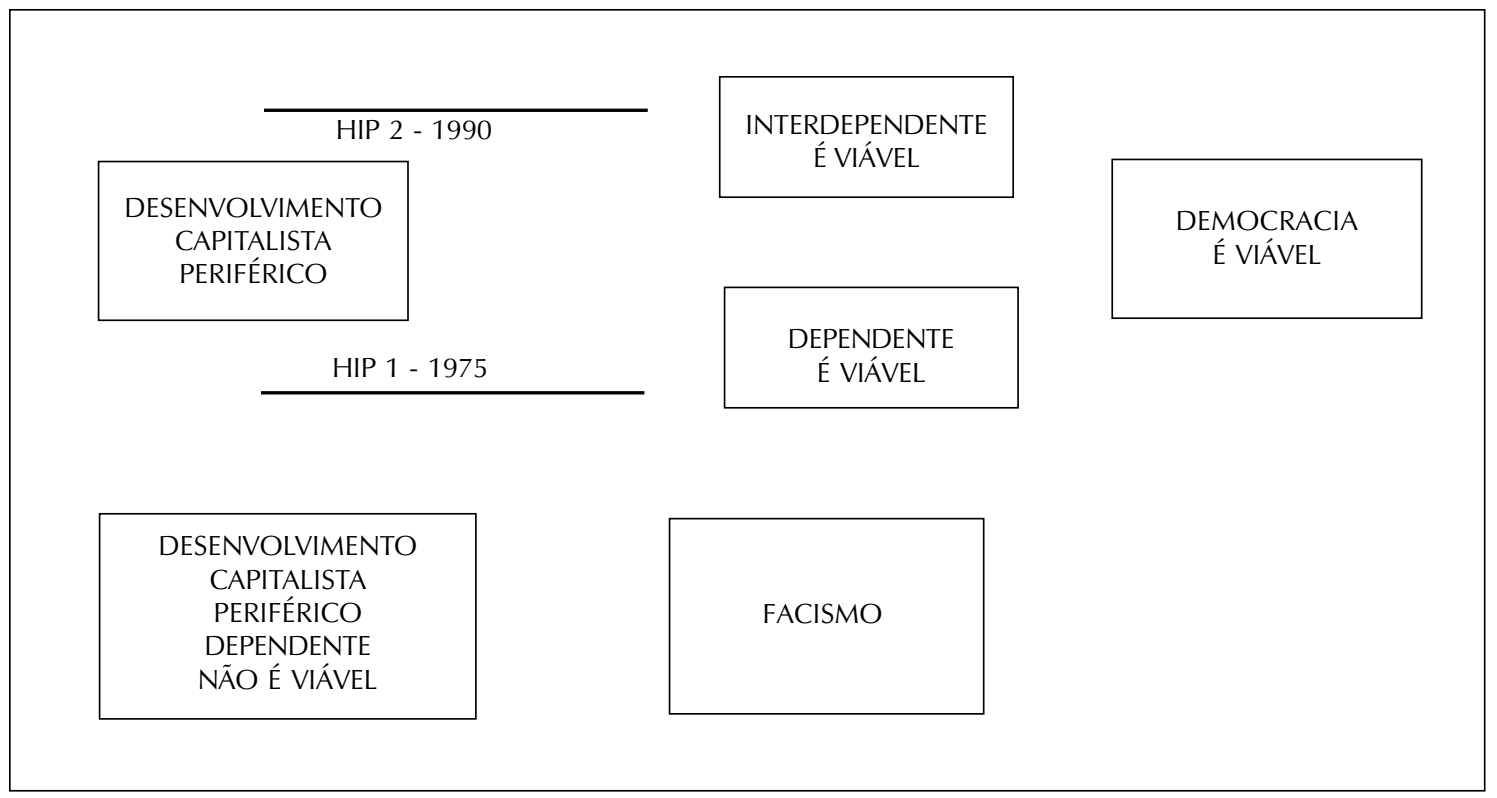

Figura 4 - Teoria da dependência e a questão democrática - hipótese dependência não estagnacionista Cardoso 
A "democratização substantiva" é concebida por Cardoso como uma tarefa anterior à definição de formas de governo e de controle partidário, que insiste sobre o direito à participação, à crítica e ao controle por parte dos indivíduos nos distintos planos da sociedade. Tratar-se-ia de buscar mecanismos que assegurassem, em primeiro lugar, informações sobre decisões (nas Empresas de Estado, na Administração etc.); em segundo lugar, tratar-se-ia de ampliar o debate dentro do âmbito do Estado e de seus prolongamentos; e em terceiro lugar, imaginar fórmulas de participação nestas decisões, tanto por parte dos que estão diretamente implicados pelo trabalho nas organizações estatais como por parte do público mais amplo. Ressalte-se que Cardoso indica que não se trata, obviamente, de substituir a luta de classes por uma panacéia de "participação indeterminada", mas de criar as arenas e o clima de liberdade que permitam aos trabalhadores, aos assalariados em geral, aos sindicatos, às organizações culturais, religiosas e políticas exercer sua ação transformadora, para isto sendo necessário reorganizar os partidos e criar associações que expressem autenticamente os interesses dos assalariados.

$\mathrm{Na}$ busca da consecução destes ideais, Cardoso ingressa na vida político-partidária em 1978, sendo eleito suplente de senador pelo MDB (Movimento Democrático Brasileiro) de São Paulo. Em 1983, assume o mandato de senador substituindo Franco Montoro e participando posteriormente da fundação do Partido da Social Democracia Brasileira.

Simultaneamente sua produção intelectual volta-se cada vez mais para a análise dos processos cotidianos e das alternativas dos sociais individuais e coletivos envolvidos na redemocratização política brasileira. A coletânea A Construção da Democracia (1993), inclui análises de temas como os governos Geisel e Figueiredo, o início da distensão política, o papel dos empresários nesta. Em suas análises, Cardoso (1988) realiza uma dura crítica a três alternativas políticas para o Brasil : a liberal-conservadora, identificada com o regime militar e a estratégia da abertura lenta e 
gradual; a liberal-democrática, voltada meramente para os aspectos jurídico-legais da redemocratização e a democrático-basista, inspirada no solidarismo cristão, no anarquismo anti-estatizante e na crença da "pureza e bondade" natural do povo.

Ressalte-se que três teses merecem atenção para a compreensão plena das idéias do sociólogo (e do político) Fernando Henrique Cardoso, as quais também podem servir como peso e medida para a avaliação de seu desempenho na Presidência do Brasil por oito anos: (1) a tese da viabilidade de algum tipo de desenvolvimento capitalista, ainda que em condições de dependência associada, com presença do capital internacional, sem que isto signifique que as burguesias locais deixem de existir; (2) a tese da viabilidade de algum tipo de (re)distribuição de renda, mesmo nessas condições; e (3) baseada nas teses anteriores, a tese da necessidade-viabilidade de uma democratização substantiva, com justiça social, participação democrática e liberdade efetiva. O deslocamento analítico ocorrido no discurso de Cardoso, com a noção de interdependência passando a assumir uma centralidade antes ocupada pelo conceito de capitalismo dependente-associado, evidentemente veio a facilitar a pregação política dessas teses, ainda que, sua efetiva concreção parece muito longe de se ter efetivado.

\section{IV - A Sociologia Brasileira hoje: em busca de uma Nova Identidade}

No período da transição democrática e implantação do sistema democrático-constitucional no Brasil, verificou-se nas ciências sociais um deslocamento temático que tem implicações teórico-práticas significativas. A ênfase em estudos relativos à dependência, vigentes na primeira metade da década de 70, veio a ser substituída, na segunda metade da década, pela temática da reativação da sociedade civil, que se transmutou 
quase que imediatamente nas temáticas dos movimentos sociais e da redemocratização. ${ }^{17}$

É interessante apontar que, não por acaso, no contexto de sucessivas derrotas das forças democrático-populares dentro do próprio processo de transição (Campanha das Diretas Já, eleições de 1989 e 1990), a temática dos movimentos sociais veio a dar lugar à pesquisa acerca das identidades sociais e representações sociais, temas estes que, a despeito de sua relevância, talvez se tenham se tornado, então, obstáculos epistemológicos, dada a imediatez, subjetivismo e empiricismo de parcela significativa dos estudos desenvolvidos. Com a perda de iniciativa dos movimentos sociais democrático-populares ao longo dos processos de redemocratização, enclausurando-se, a Sociologia seguiu um caminho epistemológico e teórico-metodológico muito problemático, com o privilegiamento de abordagens microssociais e uma ênfase exacerbada na questão das identidades, das representações e do imaginário dos agentes sociais.

A candência dos desafios colocados por esses temas pode ser avaliada tendo por referência empírica alguns aspectos principais do caso da Sociologia brasileira contemporânea. A Sociologia no Brasil, no período dos anos 60 e 70 para os anos 90, vivenciou uma passagem de análises macros-sociológicas de crítica ao modelo econômico-social excludente do "milagre" e de crítica ao modelo autoritário para uma microssociologização dos estudos. Em grandes linhas, verificou-se uma evolução temática da Sociologia brasileira nos seguintes termos: de grandes interpretações macroestruturais do modelo econômico-político-cultural do regime anterior, passou-se para a análise dos agentes e características da transição democrática, seguida dos temas da democratização necessária, dos movimentos sociais e da estratégia de reativação da socieda-

\footnotetext{
17 Como obras exemplares dessas tendências, ver São Paulo, 1975. Crescimento e Pobreza. (Camargo, 1976) e São Paulo: O Povo em Movimento. (Singer e Brandt, 1980).
} 
de civil. Rapidamente, ocorreu uma dissociação da questão dos movimentos sociais em relação a condições macroestruturais, passando a Sociologia a dedicar-se massivamente a enfocar as identidades e representações sociais dos movimentos urbanos e rurais, do movimento sindical, dos movimentos feministas e gay, do movimento negro e dos movimentos ecológicos. Filosoficamente poder-se-ia dizer que, em termos clássicos, ocorreu um tipo de passagem do privilegiamento da questão do "para-si" para o "em-si" dos movimentos sociais.

Recentemente, dentro de um contexto de busca de nova identidade das ciências sociais brasileiras, como se pode constatar face à expansão e diferenciação dos grupos de pesquisa constantes do Diretório de Grupos de Pesquisa do CNPq, novos temas e novas abordagens vieram a ser propostos para a explicação e/ou compreensão da situação social brasileira. ${ }^{18}$

O Diretório de Grupos de Pesquisa ${ }^{19}$ do CNPq indica que, em 2002, as três áreas totalizavam 477 grupos, estando inscritos 240 grupos de Sociologia, 142 grupos de Antropologia e 95 grupos de Ciência Política (Tabela 3)

Tabela 3 - Diretório de grupos de pesquisa do CNPq - Grupos de pesquisa em Sociologia, Antropologia e CIÊncia Política - 2002.

\begin{tabular}{|c|c|c|}
\hline ÁREA DO CONHECIMENTO & No DE GRUPOS & $\%$ \\
\hline SOCIOLOGIA & 240 & 1,6 \\
\hline ANTROPOLOGIA & 142 & 0,9 \\
\hline CIÎNCIA POLITICA & 95 & 0,6 \\
\hline CIÊNCIAS HUMANAS & 2.399 & 15,8 \\
\hline TOTAL DE GRUPOS & 15.158 & 100.0 \\
\hline
\end{tabular}

Fonte: Diretório de Grupos de Pesquisa do CNPq, 2002.

18 Para revisões da produção das ciências sociais brasileiras por disciplinas áreas temáticas, ver as coletâneas publicadas pela ANPOCS, sob a direção de Micelli (1999, vol. 1, 2 e 3; e 2002).

19 Para estudos acerca da Sociologia no Diretório de Grupos de Pesquisa do CNPq, ver Liedke Filho (2001 e 2003a). 
Os dados referentes à classificação das 528 linhas de pesquisa dos 240 grupos de pesquisa em Sociologia indicam, quanto às sociologias específicas integrantes da árvore do conhecimento do Conselho Nacional de Pesquisa - $\mathrm{CNPq},{ }^{20}$ que 181 linhas foram classificadas como dedicando-se à Sociologia em geral, seguindo-se por ordem de importância a sociologia do conhecimento, a sociologia urbana, a sociologia rural e a sociologia do desenvolvimento, cada uma das quais com mais de 50 classificações (Tabela 4). Entre as novas áreas temáticas, destacam-se a sociologia do trabalho, a sociologia política, a sociologia da cultura, a sociologia da educação, os estudos sobre violência e a sociologia da religião (Tabela 5).

Tabela 4 - Diretório de grupos de pesquisa do CNPq - classificação das linhas de pesquisa de Sociologia - Sociologias Específicas - 2005.

\begin{tabular}{|c|c|}
\hline SOCIOLOGIAS ESPECÍFICAS & $\mathrm{N}^{\circ}$ DE LINHAS \\
\hline SOCIOLOGIA & 181 \\
\hline SOCIOLOGIA DO CONHECIMENTO & 60 \\
\hline SOCIOLOGIA URBANA & 59 \\
\hline SOCIOLOGIA RURAL & 57 \\
\hline SOCIOLOGIA DO DESENVOLVIMENTO & 50 \\
\hline FUNDAMENTOS DA SOCIOLOGIA & 39 \\
\hline SOCIOLOGIA DA SAÚDE & 23 \\
\hline OUTRAS SOCIOLOGIAS ESPECÍFICAS & 233 \\
\hline TOTAL & 702 \\
\hline
\end{tabular}

Fonte: Diretório de Grupos de Pesquisa do CNPq, 2005.

\footnotetext{
20 Ressalte-se que pode ocorrer contagem dupla, pois uma mesma linha pode ser objeto de até três classificações. Outrossim, a classificação das áreas do conhecimento encontra-se presentemente em fase de reformulação por um esforço conjunto do Conselho Nacional de Pesquisa - CNPq e da Coordenação de Aperfeiçoamento do Pessoal do Ensino Superior - CAPES.
} 
Tabela 5 - Diretório de grupos de pesquisa do CNPq - classificação das linhas de pesquisa de Sociologia - Sociologias Específicas - 2005.

\begin{tabular}{|c|c|}
\hline OUTRAS SOCIOLOGIAS ESPECÍFICAS & TOTAL \\
\hline SOCIOLOGIA DO TRABALHO & 64 \\
\hline SOCIOLOGIA POLITICA & 42 \\
\hline SOCIOLOGIA DA CULTURA & 29 \\
\hline SOCIOLOGIA DA EDUCAÇÃO & 20 \\
\hline VIOLÊNCIA & 19 \\
\hline SOCIOLOGIA DA RELIGIÃO & 19 \\
\hline MEIO AMBIENTE & 15 \\
\hline SOCIO-DEMOGRAFIA & 14 \\
\hline RAÇAS & 10 \\
\hline GÊNERO & 10 \\
\hline SOCIOLOGIA DO CONHECIMENTO & 10 \\
\hline
\end{tabular}

Fonte: Diretório de Grupos de Pesquisa do CNPq (2005).

Outrossim, cabe destacar que dados da Federação Nacional dos Sociólogos indicam que, ao longo dos setenta anos transcorridos desde a implantação do primeiro curso de ciências sociais no Brasil, foram formados cerca de 40.000 licenciados e bacharéis, sendo que atualmente a estrutura acadêmica da área é constituída por 132 habilitações (bacharelados e licenciaturas) sediadas em 84 instituições (MEC), com cerca de 13.000 alunos. Em 2002, as três áreas - Antropologia, Ciência Política e Sociologia - totalizavam 51 cursos de pós-graduação, com um corpo docente de 901 professores em quase sua totalidade doutores, e possuindo um total de 1.742 alunos de mestrado e 1.476 alunos de doutorado. ${ }^{21}$

\footnotetext{
21 Ressalte-se também o significativo papel desempenhado pelas associações profissionais e científicas - Associação Brasileira de Antropologia - ABA, Associação Brasileira de Ciência Política - ABCP, Sociedade Brasileira de Sociologia -SBS, Associação Nacional de Pesquisa em ciências sociais - ANPOCS e Federação Nacional de Sociólogos do Brasil - FNSB, e a presença das ciências sociais na Sociedade Brasileira para o Progresso da Ciência - SBPC.
} 
Nos últimos anos, as principais abordagens que se destacam pela influência marcante que vêm exercendo sobre a Sociologia no Brasil são as de Bourdieu, Foucault, Giddens, Elias e Habermas, cujas obras, assim como as releituras de Weber, são debatidas e utilizadas como referências em ensaios e pesquisas.

Ressalte-se que o crescente privilegiamento da teoria do individualismo metodológico e da teoria da escolha racional, por parte de alguns cientistas sociais, veio a colocar questões pertubadoras, como se depreende ao enfocarem, por exemplo, temas da sociologia da educação, como a questão das oportunidades educacionais desiguais, o problema das políticas educacionais e a discussão de objetivos das práticas pedagógicas. Tratar-se-ia, por exemplo, neste último caso, de postular uma pedagogia que privilegiasse a construção/socialização de indivíduos racionais-calculistas, free-riders, tendencialmente egoístas?

Mais recentemente, as temáticas da globalização, da pósmodernidade e do multiculturalismo têm merecido destaque nos trabaIhos dos sociólogos e cientistas sociais brasileiros, ocorrendo muitas vezes a releitura de temáticas já consagradas sob a ótica das suas possíveis conexões com as temáticas emergentes como, por exemplo, religiões em contexto de globalização, ou educação e multiculturalismo.

Em resumo, ao longo deste panorama da evolução da Sociologia no Brasil, verifica-se uma diversidade de respostas para a questão de para que serve socialmente a Sociologia (e, por extensão, para que servem as ciências sociais). Instrumento de legitimação de dominação racial; instrumento de dominação de fração de classe; disciplina auxiliar do progressivismo pedagógico; instrumento de modernização societária; instrumento da libertação nacional; elemento de apoio aos esforços de democratização da sociedade brasileira. Estas são as principais respostas que emergem da análise aqui realizada. 


\section{Referências}

AZEVEDO, Fernando. A Antropologia e a Sociologia no Brasil. In: AZEVEDO, Fernando. A Cidade e o Campo na Civilização Industrial e outros Estudos. São Paulo: Edições Melhoramentos, 1962.

AZEVEDO, Fernando. A Sociologia na América Latina e particularmente no Brasil. In: AZEVEDO, Fernando. Princípios de Sociologia. São Paulo: Edições Melhoramentos, 1957.

BASTIDE, Roger e FERNANDES, Florestan. Brancos e Negros em São Paulo. 3a. ed. São Paulo: Companhia Ed. Nacional, 1971.

CAMARGO, Cândido P. et alii. São Paulo 1975: Crescimento e Pobreza. Edições Loyola, 1976.

CARDOSO, Fernando H. As Idéias e seu Lugar: Ensaios sobre as teorias do Desenvolvimento. Cadernos Cebrap 33. Petrópolis: Editora Vozes, 1980.

CARDOSO, Fernando H. Autoritarismo e Democratização. Petrópolis: Ed. Paz e Terra, 1976.

CARDOSO, Fernando H. Desenvolvimento associado-dependente e teoria democrática. In: STEPAN, Alfred (org.). Democratizando o Brasil. Rio de Janeiro: Paz e Terra, 1988.

CARDOSO, Fernando H. e Faletto, Enzo Desenvolvimento e Dependência na América Latina. Rio de Janeiro: Zahar Ed., 1973.

CARDOSO, Fernando H. e Ianni, O. 1960. Cor e Mobilidade Social em Florianópolis. São Paulo: Cia Editora Nacional.

CARDOSO, Fernando H. Empresário Industrial e Desenvolvimento Econômico no Brasil. São Paulo: Difel, 1964.

CARDOSO, Fernando H.. Capitalismo e Escravidão no Brasil Meridional. São Paulo: Difel, 1962. 
CARRI, Roberto. Pensamiento Nacional y Sociologia Antinacional, 1970. In Cortés, Rosalía. Ciencias Sociales: ideología y realidad nacional. Buenos Aires: Editorial Tiempo Contemporaneo, 1974.

CLAPCS - Centro Latino-americano de Pesquisas em Ciências Sociais. Informe Nacional sobre o Estado Atual da Sociologia no Brasil. Anuario de Sociología de los Pueblos Ibericos. 1967

$\mathrm{CNPq}$ - Conselho Nacional de Pesquisa. Diretório de Grupos de Pesquisa do CNPq. Disponível em <http://www.cnpq.br/>. Acesso: maio 2002.

COLLIER, David O Novo Autoritarismo na América. Rio de Janeiro: Paz e Terra, 1982.

CORREIA DIAS, Fernando. Comunicação. II Congresso Nacional de Sociólogos. Brasília: 1981.

COSTA PINTO, L. A. e CARNEIRO. E.. As Ciências Sociais no Brasil. Rio de Janeiro: CAPES, 1955.

CUNHA, Luiz A. Educação e Desenvolvimento Social no Brasil. Rio de Janeiro: Francisco Alves, 1979.

DAL ROSSO, Sadi. As Condições de Emprego e Salário do Sociólogo. Brasília, Departamento de Sociologia, UnB, Série Sociologia, n. 23, 1981, p. 2.

D'INCAO, Maria Angela (org.), O Saber Militante - Ensaios sobre Florestan Fernandes. Rio de Janeiro: Paz e Terra - Ed. UNESP, 1987.

DURAND, J. C. G. Sociologia do Desenvolvimento I , R. J., Zahar Ed., 1969.

FERNANDES F. A Integração do Negro na Sociedade de Classes. São Paulo: Dominus Editora e Editora da USP, 1965.

FERNANDES, Florestan. O Processo Constituinte. Brasília: Câmara dos Deputados, 1988.

FERNANDES, Florestan. 1957. Desenvolvimento Histórico-social da Sociologia no Brasil. In: FERNANDES, Florestan. A Sociologia no Brasil. Contribuição Para o Estudo de sua Formação e Desenvolvimento. Petrópolis: Vozes, 1977. 
FERNANDES, Florestan. 1958. O Padrão de Trabalho Científico dos Sociólogos Brasileiros. In: FERNANDES, Florestan. A Sociologia no Brasil. Contribuição Para o Estudo de sua Formação e Desenvolvimento. Petrópolis: Vozes, 1977.

FERNANDES, Florestan. A Ditadura em Questão. São Paulo: T. A Queiroz Ed., 1982.

FERNANDES, Florestan. A Função Social da Guerra na Sociedade Tupinambá. São Paulo: Pioneira Ed. EDUSP, 2a. ed., 1970.

FERNANDES, Florestan. A Integração do Negro na Sociedade de Classes. São Paulo: Dominus Editora e Editora da USP, 1965.

FERNANDES, Florestan. A Organização Social dos Tupinambás. 2a. ed. São Paulo: DIFEL, 1963, 1963.

FERNANDES, Florestan. A Revolução Burguesa no Brasil. Rio de Janeiro: Zahar Ed., 1975a.

FERNANDES, Florestan. A Sociologia em Uma Era de Revolução Social. 2a. ed. Rio de Janeiro: Zahar Ed., 1976b.

FERNANDES, Florestan. A Sociologia no Brasil. Contribuição Para o Estudo de sua Formação e Desenvolvimento. Petrópolis: Vozes, 1977.

FERNANDES, Florestan. A transição prolongada. São Paulo: Cortez, 1990.

FERNANDES, Florestan. Brasil em Compasso de Espera. São Paulo: Hucitec, 1980b.

FERNANDES, Florestan. Circuito Fechado. São Paulo: Hucitec, 1976c.

FERNANDES, Florestan. Democracia e Desenvolvimento - A Transformação da Periferia e o Capitalismo Monopolista na Era Atual. São Paulo: Ed. Hucitec, 1994.

FERNANDES, Florestan. Democracia e Desenvolvimento - A Transformação da Periferia e o Capitalismo Monopolista na Era Atual. São Paulo: Hucitec, 1994 
FERNANDES, Florestan. Educação e Sociedade no Brasil. São Paulo: DominusEditora da Universidade de São Paulo, 1966.

FERNANDES, Florestan. Elementos de Sociologia Teórica. São Paulo: Comp. Ed. Nacional, 1974b.

FERNANDES, Florestan. Ensaios de Sociologia Geral e Aplicada. 2a. ed. São Paulo: Pioneira Ed., 1971.

FERNANDES, Florestan. Florestan Fernandes - Pensamento e Ação (O PT e os Rumos do Socialismo). São Paulo: Ed. Brasiliense, 1989.

FERNANDES, Florestan. Folclore e Mudança Social no Brasil. 2a.ed. Petrópolis: Vozes, 1976a.

FERNANDES, Florestan. Fundamentos Empíricos da Explicação Sociológica. 4a. ed. São Paulo: TAQ, ,1980a.

FERNANDES, Florestan. Mudanças Sociais no Brasil. São Paulo: DIFEL, 1974a.

FERNANDES, Florestan. O Negro no Mundo dos Brancos. São Paulo: DIFEL, 1972.

FERNANDES, Florestan. Que Tipo de República? São Paulo: Brasiliense, 1986.

FERNANDES, Florestan. Sobre o Trabalho Teórico Entrevista Trans/form/Ação, n. 2, Assis: FFCL,1975b.

FERNANDES, Florestan. Sociedade de Classes e Subdesenvolvimento. Rio de Janeiro: Zahar Ed., 1969.

FERNANDES, Florestan. Tensões na Educação. Salvador: Editora Sarahletras, 1995.

FREYRE, Gilberto. Casa Grande e Senzala. Rio de Janeiro: Record, 2000.

GERMANI, Gino. Análise da Transição. In Costa Pinto, Luiz. A. e Bazzanella, Waldemiro. Teoria do Desenvolvimento. Rio de Janeiro: Zahar Ed., 1967.

GERMANI, Gino. La Sociología em America Latina. Problemas y perspectivas. Buenos Aires: EUDEBA, 1964. 
GERMANI, Gino. The Development and Present State of Sociology in Latin America. In Transactions of the Fourth World Congress of Sociology. Vol. I Milan and Stresa, International Sociological Association, 1959.

IANNI O. As Metamorfoses do Escravo. São Paulo: DIFEL, 1962.

IANNI, Octávio. Sociologia e Sociedade no Brasil. .São Paulo: Editora Alfa Ômega, 1975.

IANNI, Octávio. :Sociologia da Sociologia Latino Americana. Rio de Janeiro: Editora Civilização Brasileira, 1971.

IANNI, Octávio. Sociologia da Sociologia. In IANNI, Octávio. Sociologia da Sociologia Latino Americana. Rio de Janeiro: Editora Civilização Brasileira, 1971a.

IANNI, Octávio. Sociologia da Sociologia. São Paulo: Editora Ática, 1989.

IANNI, Octávio. Sociologia e Dependência Científica. In IANNI, Octávio. Sociologia da Sociologia Latino Americana. Rio de Janeiro: Editora Civilização Brasileira, 1971b.

LAMBERT, Jacques. Os Dois Brasis. Rio de Janeiro: INEP - MEC, 1959.

LAMOUNIER, Bolivar. Formação de um Pensamento Autoritário na Primeira República. Uma Interpretação.In Fausto, B. (dir.) História Geral da Civilização Brasileira. III O Brasil Republicano. Sociedade e Instituições (1889 - 1930). São Paulo: Difusão Editorial S. A., 1977.

LIEDKE FILHO, E. D. Teoria Social e Método na "Escola da USP" (1954-1962). Dissertação de Mestrado em Sociologia; Brasília: UnB, 1977.

LIEDKE FILHO, Enno D. Sociologia e sociedade no Brasil e na Argentina: 19541985. Cadernos de Sociologia, n. 2, Porto Alegre, PPG Sociologia/UFRGS, 1990b.

LIEDKE FILHO, Enno D.. A Sociologia no Diretório dos Grupos de Pesquisa do CNPq 1993-1997. In: Baumgarten, M. (org.) A Era do Conhecimento. Matrix ou Ágora. Porto Alegre, Brasília: Editora da Universidade UFRGS, UnB, 2001.

LIEDKE FILHO, Enno D.. 2003a. Sociologia Brasileira: tendências institucionais e epistemológico-teóricas contemporâneas. Sociologias, Porto Alegre, ano3, n. 9, 2003. 
LIEDKE FILHO, Enno D.. Sociology and Society in Brazil and Argentina 19541985. Ph. D. Thesis in Sociology, Brown University, Providence, RI, 1990a.

MAIO, Marcos C. e SANTOS, R. V. Raça, Ciência e Sociedade. Rio de Janeiro: Editora Fiocruz/CCBB, 1996.

MANNHEIM, Karl. Ideologia e Utopia. 2a. ed. Porto Alegre: Editora Globo, 1952.

MICELLI, Sergio (org.). História das Ciências Sociais no Brasil. São Paulo: Editora Sumaré, 1995. Vol. 2

MICELLI, Sergio (org.). História das Ciências Sociais no Brasil. São Paulo: Vértice, IDESP, Vol.1, 1989.

MICELLI, Sergio (org.). O que ler na ciência social brasileira (1970 - 1995). São Paulo: Editora Sumaré, ANPOCS; Brasília, CAPES; V. 1. Antropologia - V. 2. Sociologia - V. 3. Ciência política, 1999.

MICELLI, Sergio (org.). O que ler na ciência social brasileira 1970 - 2002. São Paulo: Editora Sumaré, ANPOCS, CAPES; 2002.

NOGUEIRA, Oracy (Coordenador) A Sociologia no Brasil: História e Situação Atual. São Paulo: Datilografado, 1982.

NOGUEIRA, Oracy. A Sociologia no Brasil. In: História das Ciências no Brasil. Vol. 3, 181-234, (s.d.).

O'DONNELL, Guillermo. Tensões do Estado Autoritário-Burocrático e a Questão da Democracia. In: Collier, David. O Novo Autoritarismo na América. Rio de Janeiro: Paz e Terra, 1982.

OLIVEIRA, J. A. M. de, et alii Manifesto de Fundação da Escola Livre de Sociologia e Política de São Paulo (1933). In: FÁVERO, M. de L. de A Universidade \& Poder. Rio de Janeiro: Achiamé, 1980.

PÉCAUT, Daniel. Intelectuais e a política no Brasil - entre o povo e a nação. São Paulo: Ática, 1990.

RAMOS, Alberto G. A Redução Sociológica. $2^{\mathrm{a}}$ ed., Rio de Janeiro: Tempo Brasileiro, 1965. 
RAMOS, Alberto G.. Cartilha brasileira de aprendiz de sociólogo. In: Ramos, Alberto G. Introdução Crítica à Sociologia Brasileira. Rio de Janeiro: Editorial Andes Ltda, 1957.

SANTOS, Theotonio. Socialismo o Fascismo. El nuevo carácter de la dependencia y el dilema latinoamericano. Buenos Aires: Ediciones Periferia, 1972.

SARTRE, Jean. P.. A Questão de Método. São Paulo: DIFEL, 1967.

SINGER, Paul. e Brandt, Vinicius. C. (orgs). São Paulo: O Povo em Movimento. Petrópolis: Editora Vozes, 1980.

SORJ, Bernardo e MITRE,Antonio. Intelectuais, Autoritarismo e Política - O Cebrap e as Ciências Sociais no Brasil. Rio de Janeiro: Datilografado, 1985.

STAVENHAGEN, Rodolfo. 1965. Sete Teses Equivocadas sobre a América Latina. In DURAND, J. C. G. Sociologia do Desenvolvimento I. R. J.: Zahar Ed., 1969. 


\section{Resumo}

Este estudo focaliza a história da sociologia no Brasil e as recepções de tradições sociológicas européias e norte-americana pela sociologia brasileira. As etapas e os períodos da evolução da Sociologia e de sua institucionalização como disciplina acadêmico-científica no Brasil são apresentados em seus traços principais, assim como a situação atual da sociologia nas universidades, os principais campos de pesquisa da sociologia brasileira e os novos temas e novas abordagens que vieram a ser propostos para a explicação e/ou compreensão da situação social brasileira.

Palavras-chave: Sociologia no Brasil, História da Sociologia no Brasil. 
Sociology in Brazil: history, theories, and challenges

\section{Enno D. Liedke Filho}

This study focuses on the history of sociology in Brazil and receptions of European and North American sociological traditions by Brazilian sociology. The stages and periods of development of Sociology and its institutionalization as an academic-scientific discipline in Brazil are presented in their main features, as well as sociology's current situation at universities, the main fields of research of Brazilian sociology, and the new themes and approaches that came to be proposed for explaining and/or understanding Brazil's social situation.

Key words: sociology in Brazil, history of sociology in Brazil. 